\title{
PRUSACY PODCHODZA POD WAWEL - PLANY OBRONY KRAKOWA Z WIOSNY 1793 ROKU
}

\section{Maciej Trąbski}

(10) http://orcid.org/0000-0003-4699-7697

Uniwersytet Humanistyczno-Przyrodniczy im. Jana Długosza w Częstochowie

\begin{abstract}
THE PRUSSIANS ARE ATTACKING THE WAWEL CASTLE PLANS OF CRACOW DEFENCE IN THE SPRING OF 1793
\end{abstract}

At the beginning of 1793, the Prussian army marched onto the territory of the western provinces of the Polish-Lithuanian Commonwealth, executing the plan of the Second Partition of Poland signed in Saint Petersburg. Due to the lack of information concerning the maximum range of the annexation in the early spring, the Confederate authorities started to fear that Cracow might be taken too by Prussia or by Austria. Thus, general Józef Wodzicki was tasked with securing the city. However, he had to face the fact that there was no possibility of planning his actions around the fortifications and that he had only modest forces at his disposal.

Keywords: Second Partition of Poland, Cracow, general Józef Wodzicki, the crown military forces, fortifications.

Słowa kluczowe: II rozbiór, Kraków, gen. Józef Wodzicki, wojsko koronne, fortyfikacje.

Rok 1793 stanowi istotną cezurę w dziejach Rzeczypospolitej Obojga Narodów. Po przegranej wojnie z Rosją nie tylko utracono odzyskaną cztery lata wcześniej suwerenność, ale ziściło się też widmo kolejnych aneksji. W dotychczasowej literaturze naukowej omówione zostały przede wszystkim polityczne uwarunkowania II rozbioru, a zwłaszcza kwestie sejmu grodzieńskiego (1793) i postanowień, jakie wówczas zapadły. Znacznie mniej miejsca zajmuje problematyka dotycząca sposobu realizacji przez Prusy i Rosję ich zaborczych planów, zwłaszcza od strony wojskowej. Odnośnie do wkroczenia wojsk pruskich znane są podstawowe fakty, takie jak: daty rozpoczęcia operacji i zajęcia najważniejszych miejscowości, siły, jakimi dysponowały Prusy, oraz ostateczny zasięg zaboru. Znacznie mniej wiadomo o próbach oporu, jakie podejmowało wojsko koronne na terenie Wielkopolski, chociaż znawcy tematu 
mogą wskazać na potyczkę w Kargowej i plan obrony Gniezna przez wicebryg. Jana Henryka Dąbrowskiego ${ }^{1}$. Natomiast mało dotychczas znana była kwestia dotycząca obaw polskich czynników wojskowych co do możliwości ataku wojsk pruskich na Kraków oraz plany obrony tego miasta.

\section{ZAGROŻENIE DLA WOJEWÓDZTWA KRAKOWSKIEGO}

Porozumienie prusko-rosyjskie dotyczące zasięgu aneksji ziem państwa polsko-litewskiego podpisane zostało w Petersburgu 23 stycznia 1793 roku$^{2}$. Informacja o dokonanych uzgodnieniach musiała jednak zostać przesłana znacznie wcześniej, gdyż już 24 stycznia pierwsze oddziały pruskie przekroczyły granicę z Rzeczpospolitą. W ciągu trzech tygodni, niemal bez oporu ze strony oddziałów wojska koronnego, udało się im zająć całą Wielkopolskę. Mające osłaniać tę prowincję oddziały Dywizji Wielkopolskiej gen. lejt. Arnolda Byszewskiego zostały zmuszone do odwrotu najpierw na linię Łęczyca-Łowicz, a następnie 18 lutego otrzymały rozkaz przejścia na teren województw sandomierskiego i krakowskiego ${ }^{3}$. Zajmując pozycje na terenie Małopolski, na skrzydłach miały utrzymywać kontakt z garnizonami w Częstochowie i w Ryczywole pod Kozienicami, a w centrum wystawić wysunięte placówki w Rawie i Piotrkowie - w razie dalszego nacisku Prusaków oddziały te miały wycofać się za rzekę Pilicę4.

$\mathrm{Na}$ terenie województw krakowskiego i sandomierskiego znajdowały się w tym czasie trzy oddziały wchodzące w skład Dywizji Małopolskiej gen. lejt. Piotra Ożarowskiego - brygada kawalerii narodowej i dwa regimenty piechoty. Wspólnie tworzyły one brygadę, pod dowództwem gen. mjr. Józefa Wodzickiego, o łącznej sile 4749 żołnierzy. Oddziały te były jednak rozproszone po dosyć znacznym terenie. I Batalion 2. Regimentu Piechoty (szefostwa gen. Wodzickiego) stacjonował razem ze sztabem regimentu w Łęcznej (komenda $\mathrm{z}$ tego batalionu znajdowała się w Lublinie), a II Batalion w Radomiu - łącznie 1395 ludzi. I Batalion 3. Regimentu Piechoty (szefostwa gen. mjr. Mikołaja Czapskiego) razem ze sztabem stał w Krakowie, a II Batalion w Kielcach i okolicach - łącznie 1382 ludzi. Natomiast szwadrony II Małopolskiej Brygady Kawalerii Narodowej, dowodzonej przez bryg. Adama

1 T. Rawski, Najście pruskie [w:] Powstanie kościuszkowskie 1794. Dzieje militarne, Warszawa 1994, s. 48-54.

2 W. Smoleński, Konfederacja Targowicka, Kraków 1903, s. 381; R.H. Lord, Drugi rozbiór Polski, Warszawa 1984, s. 224-226; M.G. Müller, Rozbiory Polski. Historia Polski i Europy XVIII wieku, tłum. M. Wrzosek-Mü1ler, Poznań 2005, s. 67.

${ }^{3}$ Zalecenie Rzewuskiemu hetmanowi polnemu koronnemu względem cofnienia wojsk polskich od Łowicza $i$ Łęczycy w Województwa Krakowskie i Sandomierskie, Archiwum Narodowe w Krakowie [dalej: ANK], Archiwum Sanguszków. Archiwum Podhoreckie III [dalej: Podh. III], VIII 4/30, s. 154; Jenerata Henryka Dąbrowskiego pamiętnik wojskowy Legionów Polskich we Włoszech poparty notami wyjaśniajacymi, Poznań 1864, s. 16; T. Raw ski, op. cit., s. 52.

${ }^{4}$ Respons Byszewskiemu generatowi leutnantowi z 18 lutego 1793 roku, ANK, Podh. II, 365, s. 10. 
Walewskiego, znajdowały się w okolicach Radomia, ze sztabem w Lipsku - łącznie 1677 ludzi. W skład Dywizji Małopolskiej wchodziły jeszcze: 5. Regiment Piechoty Fizylierów, który stacjonował na Podlasiu (z batalionami w Białymstoku i Siedlcach) i I Małopolska Brygada Kawalerii Narodowej rozlokowana na pograniczu z Prusami Wschodnimi. Dodać należy, że dowodzący Dywizją Małopolską gen. Ożarowski w omawianym okresie przebywał w Warszawie, pełniąc obowiązki dowódcy stołecznego garnizonu, a tym samym mając pod swoją komendą również 10. Regiment Piechoty 5 .

Poza wymienionymi oddziałami na terenie województwa krakowskiego stacjonowały jeszcze dwa oddziały podporządkowane Korpusowi Artylerii Koronnej - garnizon Twierdzy Jasna Góra (vel Fortecy Częstochowskiej) i kompania artylerii na Wawelu. Pierwszy z nich liczył 178 oficerów i żołnierzy 6 . Na stanie twierdzy znajdowało się 12 nowych dział spiżowych - cztery haubice 8-funtowe i osiem armat 3-funtowych, oraz 91 dział żelaznych, z czego jedynie siedem armat było „zdatnych” do użycia - jedna 12-funtowa, trzy 3-funtowe i trzy 2-funtowe?

$\mathrm{Na}$ Wawelu na początku 1793 roku stacjonowała kompania artylerii pod dowództwem płk. Krystiana Deybla, ale pod koniec marca pozostał tam już tylko pododdział (komenda), pod dowództwem kpt. Antoniego Pierścińskiego, liczący 54 oficerów i żołnierzy ${ }^{8}$. Zabezpieczali oni sprzęt artyleryjski złożony w arsenale krakowskim, w którym znajdowało się wówczas 26 dział, z czego: cztery żelazne haubice 8-funtowe, cztery spiżowe armaty 6-funtowe, sześć spiżowych armat 3-funtowych i 12 żelaznych armat 1-funtowych (w większości niesprawnych) 9

$\mathrm{Z}$ racji swojego położenia twierdza częstochowska była pierwszym posterunkiem wojska koronnego na terenie województwa krakowskiego, który stanął w obliczu zagrożenia atakiem ze strony wojsk pruskich. Chociaż formalnie podlegała generałowi artylerii koronnej, to w związku z zaistniałą sytuacją komendant fortecy mjr Marcin Wierzbowski kontaktował się niemal wyłącznie z dowódcą Dywizji Małopolskiej. Już 18 lutego informował o pojawieniu się przy granicy dwóch batalionów pruskich fizylierów ${ }^{10}$, a pięć dni później o oddziałach zbliżających się do Częstochowy ${ }^{11}$.

Generał Ożarowski natychmiast wysłał kuriera do mjr. Wierzbowskiego, zakazując mu wpuszczania obcych wojsk do twierdzy i polecając nawiązanie kontaktu z komendantem garnizonu krakowskiego. Jednocześnie przedsięwziął kroki w celu zapewnienia wsparcia dla zagrożonej fortecy. Z Kielc wysłanych zostało

${ }_{5}^{5}$ Dyslokacja Wojska Koronnego, ANK, Podh. III, IV 2/27; Raport miesięczny za miesiac luty 1793 r. [...] od komendy Dywizji Małopolskiej, ANK, Podh. III, V 2/26.

${ }_{6}^{6}$ Rawski błędnie ocenił siłę garnizonu na 100 ludzi - vide: idem, op. cit., s. 53.

${ }^{7}$ M. Trąbs ki, Twierdza częstochowska w latach Sejmu Czteroletniego i rządów targowiczan (17881793) [w:] Twierdze osiemnastowiecznej Europy. Studia z dziejów osiemnastowiecznej sztuki wojskowej, red. M. Trąbski, t. II, Częstochowa 2018, s. 268-269, 275-278.

${ }^{8}$ T. Korzon, Wewnętrzne dzieje Polski za Stanisława Augusta (1764-1794): badania historyczne ze stanowiska ekonomicznego i administracyjnego, t. 6, Kraków 1897, s. 91.

9 Idem, Wewnętrzne dzieje Polski..., t. 5, Kraków 1897, s. 47.

${ }^{10}$ Kopia listu mjr. Wierzbowskiego do gen. Czapskiego z 18 lutego 1793 r., ANK, Podh. III, VIII 6/5.

${ }^{11}$ Kopia listu do JW. Byszewskiego GL., 23 II 1793 r., z Warszawy, ANK, Podh. III, VIII/6/8. 
400 żołnierzy z ostrą amunicją ${ }^{12}$, a spod Radomia jeden ze szwadronów II Małopolskiej $\mathrm{BKN}^{13}$. Dwa kolejne bataliony do Częstochowy miał przesunąć gen. Byszewski ${ }^{14}$. Natomiast z Krakowa wysłany miał być transport broni i amunicji: cztery armaty 6-funtowe, 3273 ładunki do armat 3-i 6-funtowych oraz 70000 ładunków karabinowych. Wszystko to miało być przewiezione w tajemnicy, ale gdyby armat nie dało się schować na wozach, wówczas do twierdzy miała zostać wysłana jedynie amunicja. Razem z tym transportem wyruszyć miał ppor. art. Antoni Hoffman, 3 podoficerów i 20 kanonierów ${ }^{15}$. Jednak żadne $\mathrm{z}$ tych posiłków nie zdążyły dotrzeć do mjr. Wierzbowskiego.

Oddziały Fryderyka Wilhelma II pod twierdzę częstochowską podeszły o świcie 28 lutego. Były to dwa bataliony fizylierów i batalion huzarów, prawdopodobnie z czterema 3-funtowymi armatami, pod dowództwem gen. mjr. Karla Philippa von Pollitza. Prusacy zażądali przekazania im fortecy w związku z przesunięciem granicy na wschód od Częstochowy. W odpowiedzi mjr Wierzbowski wysłał do pruskiego dowódcy pismo nakazujące mu obronę placówki oraz prośbę o piętnastodniowe powstrzymanie się od dalszych działan - ten zgodził się jedynie na przepuszczenie kuriera do Warszawy ${ }^{16}$.

Należy przyznać, że gen. Ożarowski dokładał dalszych starań, aby zapewnić bezpieczeństwo twierdzy częstochowskiej. Nie tylko wysyłał pisma do decydentów przebywających w Grodnie - hetmana polnego koronnego Seweryna Rzewuskiego i gen. art. Stanisława Szczęsnego Potockiego ${ }^{17}$, ale skontaktował się również z ambasadorami Rosji i Prus. Ostatecznie jednak w liście do mjr. Wierzbowskiego (z 3 marca) stwierdził, że twierdza bezpośrednio mu nie podlega i dlatego nie może dać mu „wyraźnego ordynansu” - w domyśle, jak ma dalej postępować. Sugerował

${ }_{12}$ Kopia Ordynansu do W. Jaroszewskiego pułkownika, Warszawa, 23 II 1793 r., ANK, Podh. III, $\mathrm{VIII} / 6 / 9$.

${ }_{13}$ Początkowo Ożarowski planował przesunąć pod Częstochowę całą II Małopolską BKN. Zob. List gen. P. Ożarowskiego do gen. J. Wodzickiego z 26 lutego 1793 r., Biblioteka Zakładu Narodowego im. Ossolińskich we Wrocławiu [dalej: B.Ossol.] 11639 II, s. 59; Plan dyslokacji tymczasowej od granic Galicji [i] Lodomerii, zaczawszy od Krakowa do Sandomierza, ANK, Podh. III, X 1/101; T. Raw ski, op. cit., s. 53.

${ }^{14}$ List gen. P. Ożarowskiego do gen. J. Wodzickiego z 26 lutego 1793 r., B. Ossol. 11639 II, s. 59. Początkowo gen. Byszewski zobowiązał się wysłać jeden batalion z Piotrkowa - zob. Kopia listu in valore ordynansu do W. Wierzbowskiego komendanta Fortecy Częstochowskiej, 22 [23?] II [1793 r.], z Warszawy, ANK, Podh. III, VIII/6/7.

${ }^{15} \mathrm{Na}$ realizację tego planu przeznaczono 130 dukatów. Zob. Instrukacja dla JW. Pana Ruperta Linowskiego porucznika artylerii koronnej, d. 28 lutego 1793 roku w Warszawie dana, ANK, Podh. III, $\mathrm{VIII} / 7 / 2$.

${ }^{16}$ Raport powinny mjr. M. Wierzbowskiego z 1 III 1793 r., ANK, Podh. III, VIII/6/10; Opis oblężenia twierdzy, Archiwum Jasnogórskie, Actorum Provinciae Polonae, t. XIII, sygn. 543, s. 112.

1710 III 1793 r. S.Sz. Potocki zrzekł się godności generała artylerii koronnej, a tym samym funkcji komendanta twierdz koronnych. Jego obowiązki w tym względzie miał przejąc hetman S. Rzewuski. Zob. Protokoty expedycji wojskowych za komendy JW. Potockiego [...] do wojska koronnego wysztych, Biblioteka Kórnicka Polskiej Akademii Nauk 0920, k. 35. Szerzej na temat oblężenia twierdzy częstochowskiej oraz działań mających na celu jej zabezpieczenie - zob. M. Trąbski, Twierdza częstochowska, s. $270-274$. 
za to, aby kierował się własnym rozeznaniem - jeżeli uzna, że nie ma możliwości skutecznej obrony, to w celu oszczędzenia garnizonu powinien uzgodnić $\mathrm{z}$ dowódcą pruskim możliwość wycofania się do Krakowa ${ }^{18}$.

W związku z powyższym mjr Wierzbowski, nie mając nadziei na odsiecz, a także sił i środków do prowadzenia skutecznej obrony ${ }^{19}, 5$ marca przedstawił gen. Pollitzowi punkty kapitulacji. Prusacy zgodzili się, aby garnizon wyszedł z honorami, z bronią osobistą i 60 ładunkami na każdego żołnierza, ale bez artylerii, oraz otrzymał wolną drogę do Krakowa. Zobowiązali się też zapewnić konie dla oficerów oraz podwody pod kasę, aptekę i bagaże ${ }^{20}$.

Na drugi dzień mjr Wierzbowski wysłał raport do gen. Ożarowskiego, informując go o uzgodnieniu z gen. Pollitzem warunków kapitulacji oraz o planowanym wymar$\mathrm{szu}^{21}$. Żołnierze wojska koronnego opuścili twierdzę częstochowską rano 7 marca, po czym odmaszerowali przez Koniecpol do Krakowa ${ }^{22}$.

W tym samym czasie liczące około 8000 żołnierzy oddziały z Dywizji Wielkopolskiej zajmowały stanowiska w województwach sandomierskim i krakowskim, z kwaterą główną w Końskich. Tym samym teoretyczny potencjał obronny wojska koronnego na tym obszarze uległ potrojeniu. I Wielkopolska BKN stacjonować miała na zachód od Radomia, ze sztabem w Przysuchej, a poszczególnymi szwadronami w Jedlińsku, Przytyku, Skrzynnie, Studziennej, Szydłowcu i okolicznych wsiach oraz dwoma wysuniętymi w kierunku granicy pruskiej w Opocznie i Białaczowie. II Wielkopolska BKN z kolei osłaniała Kielce, ze sztabem w Żarnowie, a pododdziałami rozmieszczonymi od Fałkowa, przez Przedbórz, Strzałków, Przyrów, Lelów, Janów do Żarek, a z odwodami w Kurzelowie, Włoszczowej, Seceminie i Chęcinach. Z kolei regimenty piechoty rozstawione miały zostać w czterech liniach. Najbliżej granicy stanowiska zająć miał 7. Regiment, z pododdziałami w Koziegłowach, Siewierzu, Mrzygłodzie i Sławkowie (początkowo w Olsztynie). Za nim umieszczony został 6. Regiment - w Szczekocinach, Żarnowcu, Pilicy i Wolbromiu (początkowo zająć miał Lelów, Koniecpol, Nakło i Secemin). Dalej na wschód znajdowały się: 1. Regiment im. Królowej - w Małogoszczy i Radoszycach, osłaniający od zachodu Kielce, oraz 9. Regiment w Końskich, Gowarczowie i Odrowążu, zamykając tym samym drogi na Radom ${ }^{23}$.

${ }^{18}$ Kopia listu do JWPana Wierzbowskiego Majora, 3 marca 1793, ANK, Podh. III, VIII 6/11; T. Rawski, op. cit., s. 53.

${ }^{19}$ Kompania stanowiąca garnizon twierdzy częstochowskiej zabezpieczała ją jedynie w okresie pokoju, gdyż w razie oblężenia forteca ta powinna być broniona przez co najmniej 1000 żołnierzy z 30 działami.

${ }^{20}$ Punkty kapitulacji, 5 III 1793 r., ANK, Podh. III, VIII/6/14.

${ }^{21}$ Raport powinny, mjr M. Wierzbowski, 6 marca 1793 r., ANK, Podh. III, VIII/6/15.

${ }^{22}$ Raport mjr. M. Wierzbowskiego [z 7 lub 8 III 1793 r.], B. Ossol. 11641 Archiwum Wodzickich, s. 359

${ }^{23}$ Dyslokacja Dywizji Wielkopolskiej w województwach sandomierskim i krakowskim lokowanego dnia 6 marca 1793 roku, ANK, Podh. III, VIII 5/31, k. 1; Planta dyslokacji Dywizji Wielkopolskiej i Matopolskiej w województwach sandomierskim i krakowskim, ANK, Podh. III, X 1/101v; Jenerała Henryka Dąbrowskiego..., s. 16. 
W marcu Prusacy nadal starali się przesuwać swoje posterunki coraz dalej na wschód. Przykładowo 7 marca mjr Wojciech Bilski (II Wielkopolska BKN) raportował z Przedborza, że przybył do niego oficer z 7. Regimentu Huzarów z żądaniem ustąpienia z miasta w ciągu 24 godzin ${ }^{24}$. Ponieważ ta, jak i inne próby wypchnięcia polskich pododdziałów nie przyniosły rezultatu, 20 marca Prusacy zażądali od dowódcy Dywizji Wielkopolskiej cofnięcia posterunków na milę od brzegów Pilicy ${ }^{25}$. Generał Byszewski próbował grać na zwłokę, odwołując się do władz zwierzchnich, ale w ciągu kilku następnych dni doszło do starć pod Janowem, gdzie 200 żołnierzy pruskich zaatakowało posterunek liczący 21 żołnierzy z Dywizji Wielkopolskiej, oraz w Kromołowie, gdzie przeważające siły zaatakowały dwie kompanie z 6. Regimentu, zmuszając je do odwrotu. W odpowiedzi złożono protest u gen. Wilhelma Schwerina, ale jednocześnie oddziały koronne musiały opuścić prawy brzeg Pilicy. Tym samym pruskie wojska obsadziły linię Przedbórz-Kromołów, uzyskując podstawę do dalszych działań w kierunku górnej Wisły, w tym z możliwością ataku na Kraków $^{26}$.

W związku z pogarszającą się sytuacją strategiczną gen. Byszewski wysłał wicebryg. Jana Henryka Dąbrowskiego do Krakowa w celu nawiązania współdziałania z Dywizją Małopolską ${ }^{27}$. Ustalił on z gen. Wodzickim, że w razie zagrożenia obie dywizje przyjdą sobie z pomocą. Planowano też nawiązanie łączności operacyjnej (używając dzisiejszej nomenklatury), bez względu na to, czy Prusacy będą kontynuowali działania aneksyjne. Według wspomnień późniejszego twórcy legionów dowódca Dywizji Wielkopolskiej przystał na ten plan, ale realizację powstrzymał rozkaz gen. Ożarowskiego, który nakazał Byszewskiemu i Wodzickiemu pozostanie na dotychczasowych stanowiskach ${ }^{28}$.

\section{PLANY OBRONY KRAKOWA}

23 lutego gen. Ożarowski powierzył obronę województwa krakowskiego gen. Wodzickiemu. Dowódcą garnizonu krakowskiego początkowo był gen. Czapski, przebywający tam przy I Batalionie swojego regimentu. Ostatecznie jednak wyjechał on z miasta w pierwszej połowie marca, gdyz - jak zapisano w raporcie - „w czasie przyjścia wojska pruskiego pod Kraków bronić by się nie mógł dla zarewersowania

\footnotetext{
${ }^{24}$ Raport powinny majora Bilskiego z 7 marca 1793 roku, ANK, Podh. III, VIII 5/33, k. 1.

${ }_{25}$ Kopia listu generata leutnanta Byszewskiego do generała Józefa Wodzickiego pisanego 21 marca 1793 roku w Końskich, ANK, Podh. III, VIII 5/37, k. 1; T. Raw ski, op. cit., s. 53.

${ }^{26}$ Raport powinny generała Arnolda Byszewskiego z 25 marca 1793 roku, ANK, Podh. III, VIII 5/40, k. 1-2; T. Rawski, op. cit., s. 54.

${ }^{27}$ Dąbrowski wyjechał pod pozorem odwiedzin u krewnych.

${ }_{28}$ Jenerała Henryka Dąbrowskiego pamiętnik wojskowy Legionów Polskich we Włoszech poparty notami wyjaśniającymi, Poznań 1864, s. 17. Dąbrowski przedstawić miał jeszcze śmielszy plan - koncentracji całej armii koronnej w okolicach Krakowa, a następnie przedarcia się przez Śląsk, Morawy, Czechy, Bawarię i Szwabię do Francji. Zob. Jenerała Henryka Dąbrowskiego..., s. 17-18.
} 
się królowi JMCi Pruskiemu”"29. Na jego miejsce 24 marca „komendę w mieście Krakowie" otrzymał ppłk Adam Kczewski, również z 3. Regimentu Piechoty ${ }^{30}$.

Zgodnie z rozkazem z 23 lutego Wodzicki miał przenieść I Batalion swojego regimentu z Łęcznej do Sandomierza oraz rozciągnąć posterunki II Małopolskiej BKN od Sandomierza do Krakowa (7 szwadronów). W tym samym czasie około 200 żołnierzy z II Batalionu 3. Regimentu miało zostać przesuniętych z Kielc do Wiślicy lub Nowego Miasta ${ }^{31}$. Rozkaz ten oznaczał, że obawiano się wkroczenia także wojsk austriackich ${ }^{32}$. Jednocześnie Ożarowski informował Wodzickiego, że na teren województwa sandomierskiego wchodzić będą oddziały Dywizji Wielkopolskiej miały one tam powstrzymywać ,wojska zagraniczne” przed dalszym parciem w głąb terytorium Rzeczypospolitej ${ }^{33}$.

Główną troską gen. Wodzickiego w marcu 1793 roku było zaplanowanie obrony Krakowa. W tym czasie jego fortyfikacje składały się z dwóch zasadniczych elementów - zamku wawelskiego oraz murów miejskich. Najsilniejszym punktem był zamek, który ze względu na swoje usytuowanie mógł pełnić funkcję cytadeli, gdyż górował nad miastem i prawym brzegiem Wisły. Jego atutami były również usadowienie na skale (co utrudniało nieprzyjacielowi prace minerskie ${ }^{34}$ ), dostęp do wody („,której nikt oderżnąć nie potraf”) oraz liczne pomieszczenia z mocnymi stropami (w piwnicach i piętrach przyziemia), które można było zaadaptować na magazyny i koszary. Jednakże budynki na ulicy Kanoniczej i Grodzkiej oraz klasztor oo. Bernardynów na Stradomiu, znajdujące się o rzut kamieniem od murów zamkowych, niweczyły w dużej części korzystne położenie - „krzywe” ulice osłaniać mogły nieprzyjacielską komunikację pomiędzy zapleczem na terenie miasta a bateriami wyłomowymi ustawionymi pomiędzy budynkami u wylotu ulic i przy klasztorze ${ }^{35}$.

${ }^{29}$ Raport miesięczny za miesiąc luty $1793 \mathrm{r}$ [...] od komendy Dywizji Matopolskiej, ANK, Podh. III, V 2/26. W latach 1766-1773 Mikołaj Czapski służył w pruskim regimencie dragonów Finckensteina.

${ }^{30}$ Raport gen. Wodzickiego z 24 marca 1793 r., ANK, Podh. III, VIII 7/7.

${ }^{31}$ Dwa szwadrony II Małopolskiej BKN znajdować się miały przy sztabie w Jędrzejowie, a jeden pod Częstochową. Natomiast czterystu żołnierzy z II batalionu 3. Reg. było w marszu pod Częstochowę. Zob.: Ordynans Ożarowskiego wydany gen. Wodzickiemu 23 lutego 1793 r., ANK, Podh. III, VIII 7/1; Plan dyslokacji tymczasowej od granic Galicji [i] Lodomerii, zacząwszy od Krakowa do Sandomierza, ANK, Podh. III, X 1/101.

${ }^{32} \mathrm{Na}$ temat obaw dotyczących możliwości wkroczenia wojsk austriackich zob. Jenerała Henryka Dąbrowskiego..., s. 16; T. Kupczyński, Kraków w powstaniu kościuszkowskim, Kraków 1912, s. 31.

${ }_{33}$ Ordynans Ożarowskiego wydany gen. Wodzickiemu 23 lutego 1793 r., ANK, Podh. III, VIII 7/1.

${ }^{34} \mathrm{~W} 1772 \mathrm{r}$. Rosjanie bezskutecznie próbowali się podkopać pod zamek w celu założenia tam miny. Zob. Z. Pianowski, Wawel obronny. Zarys przemian fortyfikacji grodu i zamku krakowskiego w. IXXIX, Kraków 1991, s. 112. W 1790 r. pod Wawelem nadal znajdował się tunel, który miał prowadzić do ganku minowego. Zob. Rękopiśmienne plany Wawelu z końca XVIII wieku w Bibliotece Uniwersyteckiej w Wilnie, oprac. K. Dzikow ski, „Przegląd Historyczno-Wojskowy” [dalej: „PHW”]: 1936, z. 1, s. 125.

${ }_{35}$ Instrukcje i raporty Karola Sierakowskiego dotyczace wywiadu terenowego w przygotowaniach do wojny z Austria w 1790 r., oprac. J. Giergielewicz, „PHW” 1929, z. 1, s. 274-275. Pułkownik z Korpusu Inżynierów Koronnych Karol Sierakowski w raporcie z V 1790 r. stwierdzał, że aby zabezpieczyć zamek przed ostrzałem artyleryjskim, należałoby wyburzyć m.in. klasztor na Stradomiu, Arsenał i Bramę Grodzką oraz Dom Dziekański. Zob. ibidem, s. 275. 


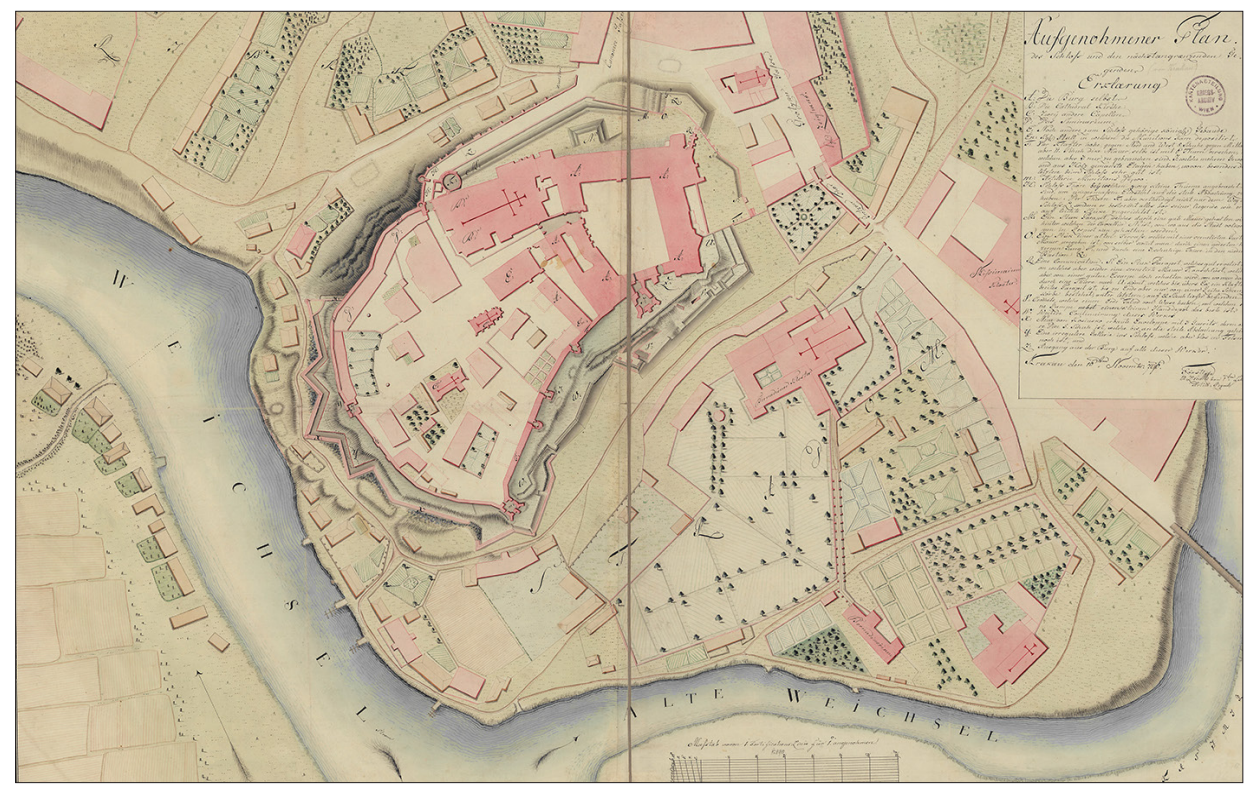

1. Plan zamku wawelskiego z 1796 roku

Österreichisches Staatsarchiv, AT-OeStA/KA KPS KS G I h, 330

Pierwotny obwód obronny wzgórza wawelskiego składał się z budynków górnego i dolnego zamku, średniowiecznego muru oraz baszt i bastei. Od południa oraz wschodu dolny zamek osłaniał mur obronny, wzmocniony pięcioma basztami dwiema dużymi: Złodziejską (od strony Wisły) i Sandomierską (od Stradomia) oraz trzema małymi: Kobiecą, Szlachecką i Tęczyńską (również od Stradomia). Do połowy lat 80 . XVIII wieku nieco poniżej południowego odcinka muru znajdował się przedmur z trzema lub czterema wykuszami, ale ze względu na zły stan w 1786 roku został on rozebrany ${ }^{36}$. Od wschodu mur przylegał do budynku kuchni królewskich, które z kolei łączyły się z południowym skrzydłem zamku górnego (parawanowym) tam znajdowała się duża Baszta Senatorska, osłaniająca wejście na teren dziedzińca arkadowego oraz kryjąca ogniem wschodnie podejście pod wzgórze. Z kolei Baszta Złodziejska, zamykająca zachodni odcinek muru, przylegała do ciągu budynków zamku dolnego (dom wikariuszy katedralnych, budynek seminarium i domy katedralne), które otaczały wzgórze wawelskie od zachodu i północy, dochodzących do głównego wejścia - Bramy Wazów. Od zachodu szyję bramną flankowały dwie małe baszty, a od wschodu basteja - „Bastion Władysława IV”"37. Dalej znajdowała się

${ }^{36}$ J. Firlet, Z. Pianowski, Fortyfikacje kleszczowe zachodniej części wzgórza wawelskiego, „Teka Komisji Urbanistyki i Architektury" 1979, t. 13, s. 17-18.

37 Według Zbigniewa Pianowskiego „Bastion Władysława IV” należałoby raczej nazywać „Basteją Augusta III", gdyż właśnie w jego czasach dzieło to otrzymało ostateczny kształt. Zob. idem, op. cit., 
katedra i zamek górny, których zewnętrzne ściany oraz przylegające do nich wieże oraz baszty zwrócone były w kierunkach północnym i wschodnim ${ }^{38}$.

Warto dodać, że w 1772 roku na rozkaz Aleksandra Suworowa u podnóża wzgórza od strony Wisły (na zachód od Baszty Sandomierskiej) zaczęto budować „szczupły bastion murowany" - miał on zasłaniać kanał, którym kilka miesięcy wcześniej na Wawel weszli konfederaci ${ }^{39}$. Nie został jednak ukończony - ponieważ brak o nim wzmianek w raportach z lat 90., prawdopodobnie został rozebrany razem z pozostałościami przedmuru.

Odnośnie do możliwości obrony tych fortyfikacji, płk Karol Sierakowski w swoim raporcie z maja 1790 roku stwierdzał, że mury zamku i katedry były mocne, a ich zewnętrzne okna mogły posłużyć za strzelnice, jednakże mur obronny był słaby i łatwo mógł zostać zniszczony ostrzałem artyleryjskim, zaś bramę zamkową można było wysadzić za pomocą petardy ${ }^{40}$. Niemniej „odważny komendant”, mający odpowiednie zapasy amunicji i żywności, mógł się bronić „dość długo”. Garnizon powinien liczyć 1200 żołnierzy piechoty i 100 kawalerii ${ }^{41}$, cztery armaty 12 -funtowe, 26 armat 6-funtowych, 16 armat 3 -funtowych oraz dwa granatniki (8-funtowe) i dwa moździerze. Spośród tych dział 16 armat 6-funtowych Sierakowski przeznaczał do baszt Senatorskiej i Sandomierskiej ${ }^{42}$, a sześć 3 -funtowych do „mniejszych wież przy bramie" - miały one być na łożach fortecznych („okrętowych”) i mogły być żelazne (a więc tańsze, lecz jednocześnie cięższe od spiżowych). Poza tym 100 żołnierzy miało być uzbrojonych $\mathrm{w}$ gwintowane sztucery ${ }^{43}$.

Najistotniejszym elementem fortyfikacji wzgórza wawelskiego były mury i wały budowane od lata 1790 roku z myślą o wojnie przeciwko Austrii. Wstępny projekt został przygotowany przez kpt. inż. Jana Mehlera, a poprawiony przez

s. 110. Z drugiej strony płk K. Sierakowski to dzieło fortyfikacyjne określił mianem „wieży”. Zob. Instrukcje i raporty Karola Sierakowskiego..., s. 276.

38 Aufgenommener Plan, das Schloss und die nächst angrenzenden Gegenden von Krakau, 1796, AT-OeStA KA KPS KS G I h, 330; Plan der Stadt und Schloss Cracau und Casimir Stadt, 1794, Staatsbibliothek zu Berlin, Kartenabteilung, sygn. SBB III C, Kart X, 38027. Zob. M. Tobiasz, Fortyfikacje dawnego Krakowa, Kraków 1973, s. 33-38, 42; Z. Pianow ski, op. cit., s. 113-115.

${ }_{39}$ Pismo płk. Jana Jakoba de Grammlicha, dowodzącego garnizonem wojska koronnego na Kazimierzu, do dowódcy Dywizji Małopolskiej. Respons na kwestie względem obrony Miasta Krakowa, jego Zamku i Miasta Kazimierza, Kazimierz 28 III 1778, ANK, Archiwum Młynowskie Chodkiewiczów [dalej: AMCh], 1160, s. 58.

40 Tadeusz Czacki rok później zapisał, że rysy na murach grożą ich upadkowi, wież nie warto opisywać, a część wałów została „dla wyjazdu pojazdów z zamku zrównana”. Zob. A. Grabow sk i, Historyczny opis miasta Krakowa i jego okolic [...] (Z rycinami), Kraków 1822, s. 264. Petarda była to puszka napełniona prochem, za pomocą której wysadzano bramy lub fragmenty palisady.

${ }^{41}$ Zadania kawalerii, „która przed zupełnym otoczeniem zamku tylko użyta być może”, obejmowały zapewne prowadzenie rozpoznania i konwojowanie transportów z zaopatrzeniem.

${ }^{42}$ Według Franciszka Ksawerego Kratzera w czasie fortyfikowania zamku w basztach Senatorskiej, Sandomierskiej i Złodziejskiej ustawiono po sześć armat. Zob. [F. Kratzer], Pamiętnik kantora katedry krakowskiej, „Biblioteka Warszawska” 1879, t. 2, s. 36. Natomiast Austriacy na planie z 1796 r. odnotowali, że spośród sześciu baszt można było używać tylko trzech - Złodziejskiej, Szlacheckiej i Senatorskiej (w Sandomierskiej znajdował się magazyn amunicji artyleryjskiej), a najlepsza z nich była ta ostatnia. Baszty te miały jednak drewniane sklepienia. Zob. Aufgenommener Plan, das Schloss, 1796.

${ }^{43}$ Instrukcje i raporty Karola Sierakowskiego..., s. 274-275. 
płk. Sierakowskiego. Natomiast oficerem odpowiedzialnym za jego realizację był kpt. inż. Jan Gawłowski ${ }^{44}$. Przed wschodnim i północnym skrzydłem zamku odtworzono szesnastowieczny przedmur, nadając mu jednak inny narys - trzech połączonych ze sobą redanów ${ }^{45}$. We wschodnim odcinku, w miejsce znajdującej się tam wyrwy o długości 65 łokci (ok. 38,7 m), wzniesiono murowany redan z wierzchołkiem zwróconym w kierunku arsenału. Na lewo od niego odtworzono niemal prosty odcinek muru, który następnie załamywał się pod rozwartym kątem w lewo, tworząc niewielki środkowy redan szczytem zwrócony w kierunku Pałacu Górków ${ }^{46}$. Na skraju lewego czoła tego redanu znajdowało się wejście w obręb fortyfikacji prowadzące do Bramy Czerwonej pomiędzy przedmurem a Kurzą Stopką ${ }^{47}$. Natomiast na prawo od pierwszego redanu mur tak jak dawniej załamywał się pod kątem prostym i dochodził do skrzydła zamkowego na wysokości Wieży Jordanka. Również północnemu murowi nadano kształt zbliżony do dwuramiennika, tyle że silnie spłaszczonego prawe jego czoło dochodziło do przejścia wiodącego do Bramy Czerwonej, lewe łączyło się z basteją przy Bramie Wazów, a wierzchołek skierowany był na Bramę vel Furtę Poboczną (wejście z Grobli na teren miasta ${ }^{48}$ ). Powyżej znajdował się odpowiadający mu kształtem wał, na którym z kolei ulokowano nadszaniec - ziemną baterię na dwa działa, frontem zwróconą w kierunku Domu Długosza i Furty Pobocznej ${ }^{49}$.

44 J. Giergielewicz, Zarys historii korpusu inżynierów w epoce Stanisława Augusta, Warszawa 1933, s. 93-97; Z. Pianowski, op. cit., s. 116-118; W. Niewalda, H. Rojkowska, Fortyfikacje kleszczowe Wawelu. Badania architektoniczne elewacji zewnętrznych, „Studia Waweliana” 1996, t. V, s. $118-119$.

45 Według raportu płk. Sierakowskiego przedmur w wielu miejscach był zrujnowany.

${ }^{46}$ Zarówno na pruskim planie Krakowa z 1794 r., jak i na austriackim planie Wawelu z 1796 r. mur owego redanu przechodził wzdłuż szyi ziemnego bastionu - obecnie znajduje się tam XIX-wieczna kaponiera. Zob. Plan der Stadt und Schloss Cracau und Casimir Stadt, 1794; Aufgenommener Plan, das Schloss, 1796. Bastionu tego ani nie odnotował Sierakowski w raporcie z V 1790 r. o stanie fortyfikacji, ani nie zaznaczył na swoim planie Mehler. Należy więc przyjąć, że został on wystawiony dopiero w czasie insurekcji.

${ }^{47} \mathrm{~W}$ ten sposób wejście zaznaczone zostało na planie pruskim, natomiast na planie austriackim widnieje ono naprzeciw Wieży Jordanka.

${ }^{48}$ Filip Lichocki na planie z 1787 r. odnotował, że Brama Poboczna była zamurowana, ale w latach 90. była już na powrót używana. Zob. idem, Dyaryusz przyjazdu Nayjaśnieyszego Stanisława Augusts [...] do stotecznego miasta Krakowa, 1787 [s. 109]. Por. Opis baszt, bram i wszelkich dóbr nieruchomych do miasta Krakowa jako własność należących (Zbiór opisów dóbr miasta stołecznego Krakowa, roku 1792), ANK, Zbiór Ambrożego Grabowskiego, sygn. 32, s. 110.

${ }^{49}$ Płk K. Sierakowski postulował „dwie kondygnacyjne baterie”, jedną w celu obrony dostępu do bramy, a drugą do zburzenia Arsenału i Bramy Grodzkiej, ,jeżeli by się tam nieprzyjaciel chciał ulokować". Przy czym w tekście raportu jest mowa o tym, że baterie usypane miały być na redanie, którym zamierzano załatać wyrwę znajdującą się naprzeciw Arsenału. Zob. Instrukcje i raporty Karola Sierakowskiego..., s. 276. Bateria w formie nadszańca znajduje się na planie Mehlera (z zaznaczonymi dwiema ambrazurami) oraz austriackim z 1796 r. Austriacy odnotowali, że dzięki temu nadszańcowi „die Stadt vollkommen in Respect kann gehalten werden". Zob. Rękopiśmienne plany Wawelu z końca XVIII wieku..., s. 129; Aufgenommener Plan, das Schloss, 1796. 
Poza tym przed północnym redanem odtworzono mur łączący zachodnią basztę przy Bramie Wazów z Furtą Poboczną ${ }^{50}$.

Główne fortyfikacje wytyczone zostały na południowym zachodzie i zachodzie wzgórza wawelskiego, u podnóża średniowiecznego muru (począwszy od Baszty Kobiecej) i domu wikariuszy katedralnych, na odcinku około 530 łokci. Był to mur o narysie kleszczowym, o wysokości od pięciu do siedmiu metrów i grubości dwóch metrów, frontem zwrócony do Wisły i granicy z Austrią. Składał się z siedmiu naroży (dwuramienników), przy czym trzecie (patrząc od strony Stradomia) ma kąt rozwarty $\left(\right.$ ok. $140^{\circ}$ ). Za murem znajdować się miały kazamaty (od strony zamku wsparte o mur oporowy), przeznaczone na stanowiska strzeleckie piechoty, z ambrazurami dla ręcznej broni palnej, natomiast nad nimi planowano tarasy artyleryjskie z wrębami w przedpiersiu. Dodatkowo część naroży (na pewno naroże nr 7) miało być wyposażonych w nadszańce, umożliwiające prowadzenie ostrzału artyleryjskiego do celów znajdujących się przed ich szczytami. Natomiast dla celów obserwacyjnych na szczycie naroży nr 1 (naprzeciw Baszty Sandomierskiej), nr 5 (naprzeciw Baszty Złodziejskiej) i nr 7 (naprzeciw domów wikariuszy katedralnych) umieszczono kawaliery - wieżyczki strażnicze ${ }^{51}$.

Należy odnotować, że prace nad tymi fortyfikacjami zostały zahamowane w drugiej połowie 1790 roku po podpisaniu austriacko-pruskiej konwencji z Dzierżoniowa, co oddaliło możliwość wybuchu wojny z południowym sąsiadem. W efekcie w marcu 1793 roku nadal brakowało stropów nad kazamatami, przez co nie było możliwości ustawienia tam dzia1 ${ }^{52}$.

Poza murami zabezpieczającymi Wawel od północy, południa i zachodu w czasie obrad Sejmu Wielkiego od strony Stradomia zaczęto sypać (odtwarzać) wał mający osłaniać znajdujący się powyżej średniowieczny mur oraz budynki zamku górnego. Ciągnął się on od Baszty Sandomierskiej w kierunku Bramy Grodzkiej, przy czym powyżej wschodniego skrzydła zamku załamywał się pod kątem prostym w lewo i dochodził do środkowego odcinka przedmuru łączącego redan z Wieżą Jordanką. Przed trzema małymi basztami wał miał narys silnie spłaszczonego redanu, a przed królewskimi kuchniami i skrzydłem parawanowym zamku prostokątny ${ }^{53}$. Również ten fragment fortyfikacji nie został ukończony do wiosny 1793 roku.

Na północ od wzgórza wawelskiego znajdowało się Królewskie, Wolne, Stołeczne i Wydziałowe Miasto Kraków. Pod koniec obrad Sejmu Wielkiego w obrębie murów miejskich, czyli w pierwszym cyrkule, było około 600 budynków, w których

${ }^{50}$ Zob. Plan der Stadt und Schloss Cracau und Casimir Stadt, 1794; Aufgenommener Plan, das Schloss, 1796.

${ }^{51}$ J. Firlet, Z. Pianowski, op. cit., s. 18-20; Z. Pianowski, op. cit., s. 117-118; W. Niewalda, H. Rojkowska, op. cit., s. 109-119. Według F. Kratzera do budowy tego fragmentu fortyfikacji wykorzystano materiały zgromadzone kilka dekad wcześniej przez bp. Kajetana Sołtyka dla podwyższenia wieży wikaryjskiej kościoła katedralnego - korzystano z „kamiennych ciosów, cegły, wapna, drzewa dębowego, sosnowego obrobionego". Zob. idem, op. cit., s. 36.

${ }^{52} \mathrm{Na}$ austriackim planie Wawelu pomiędzy drugim i trzecim narożem widać nieukończony fragment zamknięty palisadą. Notabene w opisie błędnie przypisano te fortyfikacje Tadeuszowi Kościuszce „Neue von Kosciusko erbaute Enveloppe”. Zob. Aufgenommener Plan, das Schloss, 1796.

${ }^{53}$ Z. Pianowski, op. cit., s. 118-119. 
mieszkało ponad 11000 ludzi ${ }^{54}$, a łącznie z pozostałymi trzema cyrkułami (kazimierskim, garbarskim i kleparskim ${ }^{55}$ w Krakowie było 1888 budynków i ponad 20000 mieszkańców ${ }^{56}$. Zabudowę śródmiejską (w większości murowaną) otaczał trzykilometrowy pierścień fortyfikacji o średniowiecznym rodowodzie, składających się z muru głównego, przedmuru, fosy i wału oraz baszt, bastei i umocnień przedbramnych $^{57}$. Główny mur, o pierwotnej wysokości dziewięciu metrów oraz grubości dwóch i pół metra, ciągnął się od kościoła św. Michała Archanioła (przy klasztorze Karmelitów Bosych) na północ w kierunku kościoła św. Kazimierza (oo. Reformatów), gdzie łagodnym łukiem skręcał na wschód, aby na wysokości kościoła św. Scholastyki skierować się na południe. Na odcinku od klasztoru Bernardynek mur łączył wschodnie inkastelowane pierzeje budynków, kończąc się u wylotu ulicy Grodzkiej. Podobnie po zachodniej stronie miasta, na odcinku od kościoła św. Michała do podnóża Wawelu, funkcje obronne pełniły inkastelowane budynki (domy kanoniczne), przed którymi znajdowały się ogrody klasztoru Karmelitów Bosych ${ }^{58}$.

Mur wzmocniony był 40 basztami (licząc łącznie z basztami bramnymi), rozstawionymi co 45-50 metrów na odcinku od kościoła św. Michała do wysokości kościoła św. Trójcy. W 1793 roku większość z nich znajdowała się już w złym stanie, gdyż „nakrycia ich opadły, a wiązania wewnętrzne uszkadzały słoty”"59. Tym samym ich przydatność do funkcji militarnych była niewielka.

Przedmur, o wysokości około dwóch metrów, wystawiony został pod koniec XVI wieku, w odległości około dziewięciu metrów od głównego muru obronnego ${ }^{60}$. Ciągnął się

${ }^{54}$ W spisie z 1787 r. odnotowano 11634 osoby, a trzy lata później 12 401. Należy jednak wziąć pod uwagę, że ówczesne dane zawierały również osoby mieszkające na wzgórzu wawelskim.

${ }^{55}$ Podział na cyrkuły wprowadzony został w $1792 \mathrm{r}$.

${ }^{56}$ D. Re derow a, Studia nad wewnętrznymi dziejami Krakowa porozbiorowego (1796-1809), cz. II: Zagadnienia ustrojowe i ekonomiczno-społeczne, „Rocznik Krakowski” 1962, t. XXXVI, s. 73-74; J.M. Małecki, Kraków w dobie oświecenia [w:] Dzieje Krakowa, t. 2: Kraków w wiekach XVI-XVIII, red. J. Bieniarzówna, J.M. Małe cki, Kraków 1994, s. 561, 567; P. Ję drzej ew ski, Krakowski zespół miejski - zróżnicowanie społeczne i zmiany administracyjne $w$ dobie Sejmu Wielkiego, „Małopolska regiony, regionalizmy, małe ojczyzny" 2014, t. XVI, s. 83-88.

${ }^{57}$ M. Tobias z, op. cit., s. 61. Średniowieczny był mur główny oraz większość baszt, które się w nim znajdowało (w tym wszystkie baszty bramne). Natomiast pozostałe fortyfikacje miejskie powstawały od końca XV do końca XVII w.

${ }^{58}$ Planta miasta Krakowa z przedmieściami roku MDCCLXXXV zrobiona [dalej: Plan „kołłątajowski” z 1785], Muzeum Krakowa, sygn. 31; Plan der Stadt und Schloss Cracau und Casimir Stadt, 1794; Józef Mu c zk ow s ki, Dawne warownie krakowskie, „Rocznik Krakowski” 1911,t. XIII, s. 24-25; M. Tobiasz, op. cit., s. 113-181.

59 A. Grabowski, Dawne zabytki miasta Krakowa. Przypomnienia przeszłości o niektórych starożytnych zwyczajach mieszczan krakowskich, o bramach, basztach $i$ wszelakich tej niegdyś stolicy kraju obronach, z dodatkiem różnych do dziedziny pamiątek należacych wiadomości, Kraków 1850, s. 44-45; J. Muczkowski, op. cit., s. 22; M. Tobiasz, op. cit., s. 116. W Opisie baszt, bram i wszelkich dóbr... odnotowano 40 baszt, wliczając w to dwie baszty bramne (Mikołajską i Wiślaną) - zob. ibidem, s. 101121. Natomiast na planie z $1794 \mathrm{r}$. można się doliczyć 36 baszt (nie licząc bramnych), a na planie z 1785 i na szkicu z autorstwa F. Lichockiego - 34. Zob. Plan „kołłątajowski” 1785; Plan Lichockiego z 1787; Plan der Stadt und Schloss Cracau und Casimir Stadt, 1794. Z kolei Jan M. Małecki wymienił dla tego okresu 33 baszty - zob. idem, Kraków w dobie oświecenia..., s. 561.

${ }^{60}$ A. Grabowski, Dawne zabytki miasta Krakowa..., s. 24, 65; M. Tobiasz, op. cit., s. 162. 
od Furty Pobocznej przy Domu Długosza w kierunku kościoła św. Michała (obejmując ogrody karmelickie) i dalej wokół miasta, równolegle do głównego muru, aż do Bramy Grodzkiej. Na ostatnim odcinku (ok. 500 m - od klasztoru św. Józefa do Arsenału Królewskiego), gdzie nie było już baszt, przedmur wzmocniony był trzema bastejami (,,rondelami”') ${ }^{61}$. Według inwentarza z 1792 roku dwie z nich były „ze wszystkich stron porozpadane i do rozwalenia skłonne", ale trzecia znajdowała się w dobrym stanie ${ }^{62}$.

Od północy i północnego wschodu (od wysokości kościoła św. Kazimierza do Bramy Mikołajskiej), czyli tam, gdzie teren przed fortyfikacjami był suchy i sprzyjał atakującym, znajdowała się fosa (z obmurowanym dnem i brzegami), która w razie zagrożenia mogła być wypełniana wodą z Rudawy - poprzedzona była niskim wałem ziemnym usypanym za panowania Władysława $\mathrm{IV}^{63}$. Na wschodzie od Bramy Mikołajskiej do Bramy Grodzkiej, a na zachodzie od Bramy Wiślanej do Furty Pobocznej i dalej wzdłuż wzgórza wawelskiego do Wisły fortyfikacje zabezpieczone były przez znajdujący się tam podmokły teren ${ }^{64}$.

W obu murach znajdowało się siedem bram prowadzących do miasta (część w basztach bramnych połączonych szyjami z przedbramiem) - dwie od strony wschodniej (Nowa i Mikołajska), dwie od północnej (Floriańska i Sławkowska), dwie od zachodniej (Szewska i Wiślana) oraz jedna od południowej (Grodzka). Do tego dochodziła jeszcze Brama vel Furta Poboczna, u wylotu ulicy Kanoniczej na Groble i dalej ku przeprawie na Wiśle. W czasie obrad Sejmu Wielkiego tylko trzy z nich posiadały osłaniające je fortyfikacje. Pierwszą była Brama Floriańska połączona szyją z Barbakanem (zbudowanym pod koniec XV w.), otoczonym własną fosą $a^{65}$. Drugą była Brama Sławkowska, przed którą znajdował się murowany bastion o nieregularnym narysie (zbudowany w 1683 r.), połączony z przedbramiem za pomocą szyi, pozbawiony jednak fosy. Niewielki bastion (zbudowany w latach 1655-1657) znajdował się jeszcze przed Bramą Mikołajską, przy czym w 1793 roku chylił się już ku upadkowi ${ }^{66}$.

${ }^{61}$ Plan Lichockiego z 1787; Plan der Stadt und Schloss Cracau und Casimir Stadt, 1794; M. Tobia s z, op. cit., s. 161-162, 165. Muczkowski uważał, że basteje były zniszczonymi basztami - zob. idem, op. cit., s. 22. Na planie Krakowa z 1792 r., przechowywanym w Staatsbibliothek zu Berlin (Plan von Crakau, Kartenabteilung, sygn. SBB III C, Kart X, 38026), zaznaczono 22 wykusze i basteje w linii przedmuru, co świadczy o niedokładności, z jaką został sporządzony.

${ }^{62}$ Opis baszt, bram i wszelkich dóbr..., s. 109; J. Muczkowski, op. cit., s. 22.

${ }_{63}$ Plan „kołłątajowski” z 1785; Plan der Stadt und Schloss Cracau und Casimir Stadt, 1794; A. Grabowski, Dawne zabytki miasta Krakowa..., s. 34, 65. W XVII w. fosa musiała sięgać dalej na południe, do Bramy Nowej - zob. J. Muczkow ski, op. cit., s. 21. Fosa wokół Barbakanu miała 24 m szerokości i 3,4 m głębokości. Zob. J. Muczkowski, op. cit., s. 28; M. Tobiasz, op. cit., s. 76. Fosa biegnąca wzdłuż przedmuru była prawdopodobnie węższa.

${ }^{64}$ Plan der Stadt und Schloss Cracau und Casimir Stadt, 1794; J. Muczkow ski, op. cit., s. 21-24; M. Tobiasz, op. cit., s. 66-67, 76.

${ }^{65}$ Fosę w razie potrzeby wypełniano wodą z Rudawy. Vide: M. Tobias z, op. cit., s. 76.

${ }^{66}$ Opis baszt, bram i wszelkich dóbr..., s. 106, 119; Plan „kołłątajowski” z 1785; Plan Lichockiego z 1787; Plan der Stadt und Schloss Cracau und Casimir Stadt, 1794; A. Grabowski, Dawne zabytki miasta Krakowa..., s. 74-77; J. Muczkow ski, op. cit., s. 22-24, 44; M. Tobiasz, op. cit., s. 69-112. W Opisie baszt, bram i wszelkich dóbr... przy Bramie Szewskiej odnotowany jest „rondel murowany”, którego jednak nie widać na planach z końca XVIII w. - zob. ibidem, s. 115; A. Grabowski, Dawne zabytki miasta Krakowa ..., s. 31-32. Natomiast na planie Lichockiego zaznaczone są pozostałości po 
Warto dodać, że w 1770 roku przed północno-zachodnim zakolem murów, na wysokości kościoła św. Kazimierza, z polecenia płk. Franciszka Rudolfa Oebschelwitza (rosyjskiego komendanta Krakowa) zaczęto sypać bastion, z którego artyleria mogła ostrzeliwać podejścia do bram Szewskiej i Sławkowskiej oraz osłaniać przylegające fragmenty murów ${ }^{67}$. Dwa lata później, tym razem prawdopodobnie na polecenie polskiego dowódcy - gen. mjr. Karola Albrechta Schacka, wykopano fosę na odcinku pomiędzy Bramą Nową a Bramą Grodzką, którą wzmocniono „rogatkami” (czostkami?). Jednakże już w 1778 roku ledwie można było dostrzec ślady po rowie obronnym, a „rogatki” całkiem zniknęły. Rosyjski bastion w tym czasie miał jeszcze od 10 do 12 stóp wysokości i wymagał tylko odnowienia, ale w 1793 roku już go nie odnotowywano ${ }^{68}$.

Murami o rodowodzie średniowiecznym otoczony był również Kazimierz. Wejście na jego teren zabezpieczały trzy bramy, jednakże w latach 1790-1793 brakowało już innych elementów fortyfikacyjnych, które istniały lub były planowane w poprzednich dekadach ${ }^{69}$. Po przebudowie w latach 1733-1751 walory obronne stracił kościół Na Skałce, który wcześniej flankował południowe podejście do zamku i pozbawionego murów Stradomia ${ }^{70}$. W 1770 lub 1771 roku z polecenia płk. Oebschelwitza sypane miały być fortyfikacje osłaniające Kazimierz od południa - rawelin przed Bramą Wielicką, prowadzącą do mostu na Wiśle, oraz reduta „w lewo [...] od mostu, naprzeciw solnego składu". Osiem lat później pozostały po nich już tylko ślady ${ }^{71}$. Być może drugie $\mathrm{z}$ tych dzieł można wiązać z ziemnym bastionem przylegającym do murów miejskich od zachodu, na wysokości kościoła św. Wawrzyńca, którego zarysy widać na planach miasta z lat 70. i 90. XVIII wieku².

Należy odnotować, że płk Sierakowski, przygotowując w maju 1790 roku swój raport ze stanu fortyfikacji krakowskich, nie widział możliwości obrony miasta, gdyż jego mury nie stanowiły poważnej przeszkody, a do tego należałoby je obsadzić licznym wojskiem ${ }^{73}$. Z drugiej jednak strony, aby skruszyć nawet słabe średniowieczne mury (w rozsądnym czasie) nieprzyjaciel potrzebował artylerii o większym wagomiarze (co najmniej 12-funtowej), inaczej jedynym sposobem ataku (wobec braku

ziemnej fortyfikacji przed Bramą Wiślaną, które nie zostały wykazane w innych źródłach i opracowaniach.

${ }^{67}$ W latach 1655-1657 Szwedzi w tym samym miejscu również wystawili bastion, więc prawdopodobnie Rosjanie wykorzystali jego pozostałości. Zob. J. Muczkowski, op. cit., s. 24.

${ }^{68}$ Respons na kwestie względem obrony Miasta Krakowa..., s. 57-58; A. Grabowski, Dawne zabytki miasta Krakowa ..., s. 77-78. Lichocki na planie miasta bastion opisał jako „rądel nowy z ziemi zepsuty”. Jego zarys widać też na planie „kołłątajowskim” z 1787 r., ale na pruskim planie z 1794 r. trudno już rozpoznać w nim dzieło fortyfikacyjne.

69 J. M. Małecki, Kraków w dobie oświecenia..., s. 563.

${ }^{70}$ M. Tobiasz, op. cit., s. 22-23.

${ }^{71}$ Respons na kwestie względem obrony Miasta Krakowa..., s. 57.

72 Plan der Stadt Krakau, Handzeichnung, ca. 1780 [ok. 1770?], http://www.deutschefotothek.de/ documents/obj/70400121; Plan der Stadt und Schloss Cracau und Casimir Stadt, 1794.

${ }^{73}$ Instrukcje i raporty Karola Sierakowskiego..., s. 275. Według Jana Pachońskiego do obrony murów Krakowa pod koniec XVIII w. potrzeba byłoby ok. 4000 żołnierzy. Zob. J. Pachoński, Dawne mury floriańskie, Kraków 1956, s. 33. 
breszy wybitych przez kule armatnie) pozostawała eskalada, czyli szturm przy użyciu drabin, a to już było ryzykowne przedsięwzięcie.

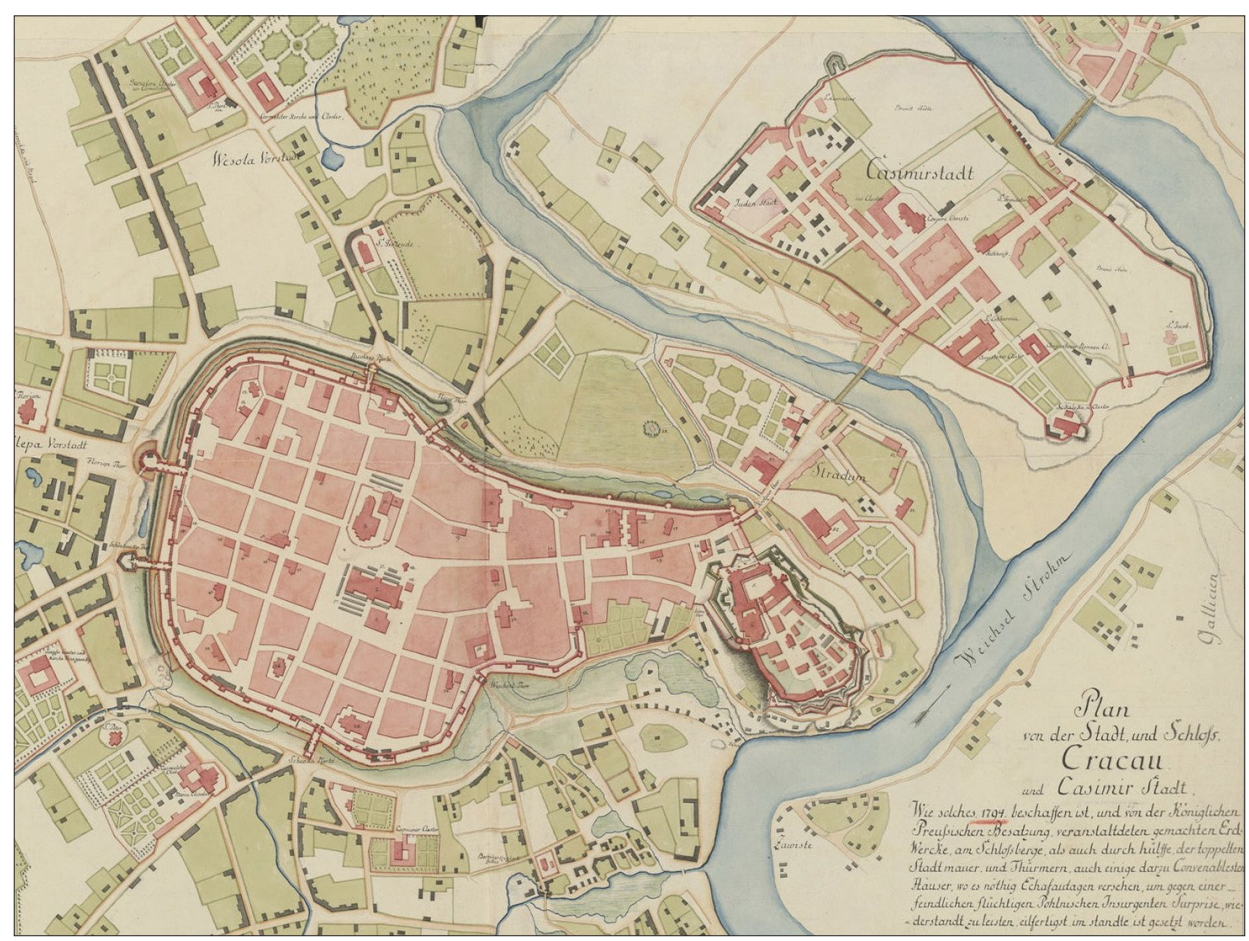

2. Fragment planu Krakowa z 1794 roku

Plan der Stadt und Schloss Cracau und Casimir Stadt, 1794, Staatsbibliothek zu Berlin, Kartenabteilung, sygn. SBB III C, Kart X, 38027

Pierwsze kroki w kierunku przygotowania Krakowa do obrony poczynił gen. Czapski na przełomie lutego i marca 1793 roku. W raporcie z 6 marca stwierdzał, że zlecił przygotowanie wstępnego planu kpt. Gawłowskiemu ${ }^{74}$. Co ciekawe, wśród dokumentów znajduje się kopia listu „Obywateli miasta Krakowa” do gen. Czapskiego. Zawarte jest w nim ostrzeżenie, a w zasadzie groźba - obywatele Krakowa, mając dość ucisku i nierządu władz konfederackich i rosyjskich, postanowili powstrzymać gen. Czapskiego przed próbami stawienia oporu „zagranicznemu wojsku", nie chcąc, aby miasto poniosło dodatkowe straty. Autorzy ostrzeżenia stwierdzili, że gen. Czapski może poinformować o tym swoich przełożonych. Zakończyli zaś słowami: „Taka jest determinacja nasza w dzisiejszych pogłoskach, które [...] daj Boże aby były fałszywe, a my nie byli przymuszeni dowieść skutkiem"775.

${ }^{74}$ Extrakt z raportu gen. Czapskiego, Kraków, 6 III 1793 r., ANK, Podh. III, VIII 7/3.

${ }^{75}$ Kopia listu do gen. Czapskiego, ANK, Podh, III, VIII 7/19; T. Kupczyński, op. cit., s. 31. 
Kapitan Gawłowski nie ukrywał, że obrona zamku z góry skazana była na porażkę, gdyż fortyfikacje nigdzie nie były ukończone ani nie widział możliwości ich dokończenia w najbliższym czasie, „,choćby też potemu największego starania i kosztu nie żałowano". Postulował więc wykonanie przeszkód w miejscach, gdzie nieprzyjaciel miałby najłatwiejszy dostęp, za którymi miały się znajdować stanowiska artylerii lub piechoty. Jeżeli starczyłoby czasu i siły roboczej, należało wykonać tam przekopy i przedpiersia. Ostatecznie można było się jeszcze bronić w starych murach, przede wszystkim w basztach (określanych przez niego mianem wieży). Co do miasta wskazywał, że otaczające je mury także dają bardzo małe możliwości prowadzenia działań obronnych, ,jako dawnym tylko sposobem wyprowadzone i przy tym [...] bardzo porujnowane" ${ }^{\text {"76 }}$. Tylko przy Bramie Sławkowskiej można było jego zdaniem w krótkim czasie przygotować stanowiska artyleryjskie - przy pozostałych nie było takiej możliwości ${ }^{77}$. Jedynym rozsądnym wyjściem byłoby wzniesienie fortyfikacji ziemnych przed bramami i w innych ku temu stosownych miejscach (m.in. koło mostu na Wiśle) - miałyby to być szańce, baterie i flesze ${ }^{78}$.

Należy dodać, że w marcu 1793 roku nadal nie było decyzji dotyczącej wstrzymania lub dokończenia prac przy fortyfikowaniu Wawelu. W raporcie z bieżącej działalności Korpusu Inżynierów Koronnych płk Sierakowski stwierdził, że na ich finalizację potrzeba będzie jeszcze nieco ponad 100000 złp. Natomiast gdyby prace miały zostać wstrzymane, to i tak należało wyłożyć ponad $10000 \mathrm{złp} \mathrm{w} \mathrm{celu} \mathrm{dokończenia}$ wałów i zabezpieczenia ,podkopanej góry"79.

W połowie marca gen. Wodzicki, widząc narastające zagrożenie, postanowił skoncentrować w Krakowie oba podległe mu regimenty piechoty i pięć szwadronów z II Małopolskiej BKN. 23 marca obok stacjonującego tam batalionu z 3. Regimentu znajdował się już jeden z batalionów 2 . Regimentu oraz były garnizon twierdzy jasnogórskiej ${ }^{80}$. Tego samego dnia przybył z Kielc drugi batalion z 3. Regimentu, który przyprowadził cztery armaty „,bardzo małe i w lichym stanie i do tego [ze] szczupłą

${ }^{76}$ W 1792 r. odnotowano w murach szereg pęknięć, a w niektórych miejscach wyrwy. Zob. Opis baszt, bram i wszelkich dóbr..., s. 101-121.

77 Odnośnie do Bramy Sławkowskiej działa zamierzał prawdopodobnie umieścić w osłaniającym ją bastionie, po jego naprawie. W 1771 r. płk. Oebschelwitz nakazywał podwyższyć ten bastion krakowskiej radzie miasta - zob. A. Grabowski, Dawne zabytki miasta Krakowa..., s. 75; J. Muczkow ski, op. cit., s. 44. Warto też odnotować, że kpt. Gawłowski nie widział możliwości umieszczenia artylerii w Barbakanie i w małym bastionie przed Bramą Mikołajską. Tym samym twierdzenie Tobiasza o zachowaniu przez Barbakan walorów bojowych aż do XIX w. (dzięki trzymetrowej grubości murów) pozbawione jest podstaw. Zob. M. Tobi as z, op. cit., s. 76.

${ }^{78}$ Raport kpt. Gawłowskiego dotyczący możliwości obrony Zamku Wawelskiego i Krakowa, 6 III 1793 r., ANK, Podh. III, VIII 7/4.

${ }^{79}$ Raport płk. Karola Sierakowskiego z 20 marca 1793 r., ANK, Podh. III, VIII 7/5. W 1790 r. Sierakowski koszt ufortyfikowania wzgórza wawelskiego obliczał na co najmniej 140000 złp, gdyż „sprowadzenie chrustu na faszyny, kopanie fundamentów na mury, wybranie ziemi z miejsca jednego i przewiezienie na inne nie może być wyrachowane dokładnie". Zob. Instrukcje i raporty Karola Sierakowskiego..., s. 276. W rzeczywistości w ciągu dwóch lat wydano na ten cel dwa razy więcej ok. 300000 złp. Zob. J. Firlet, Z. Pianow skiego, op. cit., s. 18.

${ }^{80}$ Lokacja Regimentu Pieszego pod imieniem Królewicza szefostwa J. Wielmożnego Wodzickiego w mieście Krakowie na kwaterach, 23 III 1793 r., ANK, Podh. III, VIII 7/6. 
amunicją"81. Biorąc pod uwagę wcześniejsze informacje dotyczące stanu arsenału w Krakowie oraz późniejsze dane na ten temat, te armaty można zidentyfikować jako 4-funtowe jednorogi (rodzaj haubicoarmaty) ${ }^{82}$. W raporcie z 24 marca gen. Wodzicki spodziewał się, że w ciągu 5 lub 6 dni do Krakowa przybędzie drugi batalion 2. Regimentu i pięć szwadronów kawalerii narodowej. Liczył, że mając do dyspozycji takie siły, będzie mógł powstrzymać nieprzyjaciela od „raptownego” wejścia do powierzonego mu miasta, ale nie ukrywał, że nie widzi szans na długotrwałą obronę, zwłaszcza jeżeli przeciwnik będzie liczniejszy i uzbrojony w działa. Poza wymienionymi powyżej oddziałami gen. Wodzicki otrzymał pozwolenie użycia w razie potrzeby dwóch batalionów z 9. Regimentu ${ }^{83}$, który w ostatniej dekadzie marca miał zostać przesunięty do Lipowca (na zachód od Babic). Planował, że w razie ataku wojsk pruskich oddziały te zajmą stanowiska pod Czerwonym Prądnikiem ${ }^{84}$.

Obrony samego Krakowa gen. Wodzicki nawet nie rozpatrywał. Miasto było nie tylko zbyt rozległe, jak na posiadane przez niego siły, ale dodatkowo mury w wielu miejscach były „obalone”, a na odcinku od zamku do Bramy Wiślanej w przedmurze powybijane zostały przejścia prowadzące do klasztorów i domów kanonicznych, zabezpieczone jedynie deskami. Problemem był też brak magazynu z żywnością chociaż tutaj generał widział możliwość szybkiego zakupienia wołów, wódki i innych potrzebnych produktów, jeżeli tylko władze konfederackie wydadzą stosowne polecenie, dzięki czemu można byłoby wyżywić oblegany garnizon przez dwa lub trzy dni. Jednakże nie mając nadziei na odsiecz, i tak trzeba byłoby Kraków poddać, wystawiając miasto na rabunek zdobywców. Kolejny problem stanowiło 600 żołnierzy rosyjskich stacjonujących w Krakowie ${ }^{85}$, którzy według Wodzickiego raczej przeszkadzaliby, niż pomagali obrońcom. Na koniec stwierdzał, że w razie stawienia

${ }^{81}$ Raport gen. Wodzickiego z 24 marca 1793 r., ANK, Podh. III, VIII 7/7. 130 żołnierzy z garnizonu jasnogórskiego przybyło do Krakowa 18 marca. Wobec braku kwater w mieście początkowo zamierzano ulokować ich na zamku, ale ostatecznie rozmieszczono na terenie Kazimierza - zob. Pismo Komisji Kwaterunkowej do Konfederacji Województwa Krakowskiego z 18 marca 1793 r., ANK, Akta Konfederacji Targowickiej Województwa Krakowskiego [dalej: AKTWK], sygn. 5, s. 31, Pismo przedstawicieli władz Kazimierza do Konfederacji Województwa Krakowskiego z 25 marca 1793 r., ibidem, sygn. 7, s. $561-562$.

82 Szerzej na temat tych jednorogów - zob. M. Trąbski, Artyleria wojska koronnego w pierwszym etapie powstania kościuszkowskiego (bitwy pod Racławicami i Szczekocinami) [w:] Wśród dymu i ognia. Studia i materiały do dziejów artylerii polskiej i obcej, t. II, red. A. Smoliński, Oświęcim 2016, s. 47,52 .

${ }^{83}$ Raport gen. Wodzickiego z 24 marca 1793 r., ANK, Podh. III, VIII 7/7.

${ }^{84}$ Kopia listu generata leutnanta Byszewskiego do generała Józefa Wodzickiego pisanego 21 marca 1793 roku w Końskich, ANK, Podh. III, VIII 5/37, k. 1; Raport powinny, gen. J. Wodzicki, 07.04.1793 r., ANK, Podh. III, VIII 7/16.

85 Żołnierze rosyjscy częściowo zakwaterowani zostali w koszarach (130), czyli w dawnym kolegium jezuitów przy ul. Szczepańskiej, a pozostali w domach prywatnych na terenie Krakowa oraz na Kazimierzu, Stradomiu i Pobrzeziu (140). Zob. AKTWK, sygn. 4, s. 723-729; ibidem, sygn. 7, s. 503, 561. T. Kupczyński, op. cit., s. 24-25. Z raportu gen. Wodzickiego wynika, że w koszarach w drugiej połowie III 1793 r. kwaterowały też dwie kompanie z jego regimentu (361 żołnierzy). Pozostałe rozkwaterowane zostały po domach prywatnych: jedna w Krakowie, trzy na Kleparzu, Garbarach, Grobli i Rybakach, a ostatnie dwie na Kazimierzu i Stradomiu. Zob. Lokacja Regimentu Pieszego... 
oporu wojskom pruskim na przedpolu miasta ostatecznie będzie musiał wycofać się do zamku, a następnie starać się otrzymać dobre warunki kapitulacji - wolne wyjście całego garnizonu razem ze wszystkimi „polowymi rekwizytami” oraz skarbcem i insygniami królewskimi ${ }^{86}$.

W drugiej połowie marca mogło się wydawać, że wojska pruskie zakończyły swój marsz w głąb Rzeczypospolitej ${ }^{87}$. Jednakże 27 marca hetm. Rzewuski wydał w Grodnie ordynans nakazujący strzeżenie granic województw małopolskich krakowskiego i sandomierskiego ${ }^{88}$. Zapewne $\mathrm{w}$ związku $\mathrm{z}$ tym na przełomie marca i kwietnia gen. Wodzicki przygotował kilkustronicowy dokument zatytułowany Jakim sposobem miasto Kraków i Zamek przy teraźniejszej sytuacji postapić sobie mogły podczas alarmu i ataku otoczacego kordon. Odnośnie do obrony samego miasta $\mathrm{w}$ pierwszych zdaniach ponownie stwierdził, że jest ona niemożliwa ze względu na duży obszar, zniszczone mury i obecność garnizonu rosyjskiego. Jedyne, co można było w takiej sytuacji uczynić, to stawić krótki opór, dając tym samym czas na wycofanie głównych sił na zamek. Aby garnizon nie został jednak zaskoczony „raptownym najściem”, w każdej bramie oraz furcie należało postawić posterunek złożony z jednego podoficera i dwunastu szeregowych. Hauptwach (odwach przy ratuszu) stanowić miał rezerwę, która w razie potrzeby miała przyjść z odsieczą posterunkom przy bramach Szewskiej, Wiślanej i Nowej. Przy ratuszu znajdować się też miało siedmiu żołnierzy kawalerii (towarzysz i sześciu szeregowych), którzy rozwoziliby rozkazy do poszczególnych posterunków. Te trzy bramy należało utrzymać najdłużej, gdyż tamtędy miały się wycofywać na zamek komendy z przedpola miasta. Po ich przejściu bramy miały zostać zatarasowane. Jeżeli nieprzyjaciel atakowałby bramę „armatnim ogniem”, wówczas posterunek miał odpowiedzieć strzałami, aby „ślad czynionego gwałtu zostawić”. Następnie żołnierze mieli wycofać się do zamku bocznymi uliczkami, nieznanymi napastnikom. Natomiast gdyby do sforsowania bram nieprzyjaciel wysłał tylko cieśli z toporami, wówczas należało wytrwale bronić im dostępu ogniem karabinowym. Można też było nad bramami przygotować garnki z kulami lub kamieniami do obrzucania nimi cieśli, co miało być nad wyraz skuteczne. Widać zatem, że gen. Wodzicki mimo wszystko planował jednak stawić opór (choćby symboliczny) na linii murów miejskich.

Posterunek znajdujący się przy moście na Kazimierzu powinien być dowodzony przez oficera i być silniejszy niż pozostałe ${ }^{89}$. Poza tym jego dowódca musiał mieć do dyspozycji dwóch konnych, którzy mogli być użyci do szybkiego poinformowania komendanta miasta o nadchodzącym nieprzyjacielu. Wówczas żołnierze mieli

${ }^{86}$ Raport gen. Wodzickiego z 24 marca 1793 r., ANK, Podh. III, VIII 7/7.

${ }^{87}$ Raporty gen. Wodzickiego z 24 i 30 marca - zob. ANK, Podh. III, VIII 7/7 i 7/8.

${ }^{88}$ Spis ordynansów Rzewuskiego do Dywizji Małopolskiej (14 marca-7 kwietnia), ANK, Podh. III, V $2 / 27$.

${ }^{89}$ Według Franciszka Kratzera na Kazimierzu wojsko koronne miało odwach w Glinianej Bramie. Zob. [F. Kratzer], op. cit., s. 40. 
zdemontować część mostu znajdującą się po polskiej stronie, a następnie wycofać się do korpusu znajdującego się poza miastem lub na Wawel ${ }^{90}$.

Wodzicki domniemywał jednak, że nieprzyjaciel zamiast próby gwałtownego wejścia zatrzyma się przed murami miasta i zażąda jego kapitulacji. Wówczas, aby nie tracić czasu, a z drugiej strony nie narażać mieszkańców na reperkusje związane ze szturmem po odrzuceniu wezwania, należało czym prędzej wycofać żołnierzy z posterunków do zamku.

Teoretycznie zamek miał dużo większe możliwości ze względu na swoje położenie. Jego komendant powinien jednak wcześniej zaopatrzyć magazyn w żywność, kupując ją w mieście (chleb, kilka wołów, kilka korców kaszy, kilka beczek gorzałki oraz nieco octu i wina dla chorych). Następnie, przygotowując się do obrony, powinien przy każdym oknie zamkowym (wychodzącym na zewnątrz) ustawić „dużego infanterzystę", a przy każdych drzwiach i na „wystawach” dobrego strzelca ${ }^{91}$. Schody i wyjścia ze słabymi drzwiami miały zostać zatarasowane, a na najwyższych kondygnacjach budynków i na murach miały być przygotowane kamienie „dla przywitania nimi nieprzyjaciela”. Warta stojąca przy przewozie powinna zebrać wszystkie promy i czółna.

Murów i budynków nie należało silnie obsadzać, a większość żołnierzy przeznaczyć do odwodu. Trzeba wskazać, że odnośnie do tego gen. Wodzicki był niekonsekwentny, gdyż najpierw pisał o trzech lub czterech pododdziałach, które miały interweniować w miejscu zagrożonym przez nieprzyjaciela, a kilka linijek niżej, że rezerwę można podzielić na dwie części - jedną ustawiając na zamkowym dziedzińcu, a drugą przed katedrą (,wielkim kościołem”).

Zdaniem Wodzickiego nie można było jednak myśleć o odparciu formalnego oblężenia. Już na samym początku stwierdzał, że nieprzyjaciel przygotowując się do ataku na zamek, będzie mógł wykorzystać znajdujące się u stóp wzgórza budynki kościelne oraz klasztorne ${ }^{92}$, ustawiając przy nich baterie demontujące i burzące. Poza tym skuteczną obronę uniemożliwiały niedokończone fortyfikacje (m.in. bez parapetów) i słabe stare mury zamkowe oraz niewielki garnizon „bez należytej artylerii”. Jedyne, co można było zrobić, to trzymać się „reguł polowych w bronieniu się”. Dwie armaty należało umieścić w głównej bramie zamkowej, a dwie kolejne nabite kartaczami w bocznej Bramie Czerwonej, tak aby nieprzyjaciel - gdyby nagłym

${ }_{90}$ Ten fragment pokazuje, że obawiano się też wejścia Austriaków. Rok później Austriacy rozważając możliwość zajęcia Krakowa, doszli do wniosku, iż najłatwiej będzie tego dokonać właśnie od strony Kazimierza, gdzie praktycznie nie było innych przeszkód poza koniecznością przeprawy przez Wisłę. Zamek zmuszony miał być do kapitulacji ostrzałem pociskami zapalającymi (z haubic lub moździerzy). Do całej operacji miały wystarczyć cztery bataliony piechoty z kilkoma działami o większym wagomiarze oraz nieco kawalerii. Zob. T. Kupczyński, op. cit., s. 208; B. Szyndler, Powstanie kościuszkowskie 1794, Warszawa 2001, s. 192.

${ }^{91}$ Warto przypomnieć, że płk Sierakowski w 1790 r. postulował, aby na uzbrojeniu garnizonu broniącego zamku znajdowało się 100 gwintowanych sztucerów, a w III 1793 r. w obu regimentach (2. i 3.) było łącznie 236 strzelców.

92 Warto zauważyć, że gen. Wodzicki nie zamierzał zajmować pozycji w klasztorze oo. Bernardynów na Stradomiu, który pierwotnie dostosowany był do celów obronnych - jego najsilniejszym stanowiskiem było puntone w południowym narożniku (od strony Kazimierza). 
atakiem ( a coup de main) zdobył miasto i podchodził pod zamek - był rażony ogniem krzyżowym. Resztę dział należało pozostawić w rezerwie do wykorzystania według nadarzającej się potrzeby. Dodatkowo, podobnie jak w mieście, nad bramą należało umieścić garnki z kulami lub kamieniami.

Gdyby jednak nieprzyjaciel zamiast ataku wybrał drogę pertraktacji, wzywając komendanta zamku do kapitulacji, wówczas ten miał najpierw odrzucić takowe żądanie, a dopiero za drugim razem, uczyniwszy tym samym „zadość powinności”, starać się wynegocjować jak najkorzystniejsze warunki - garnizon miał otrzymać zgodę na wyjście z twierdzy z honorami, razem z najlepszymi działami i całym ekwipunkiem, i udanie się na teren nieobjęty kordonem. Komendant miał też zabezpieczyć skarbiec katedralny, opieczętowując go, a wcześniej zapewne spisując znajdujące się tam precjoza ${ }^{93}$.

$\mathrm{Z}$ planem obrony zamku koresponduje drugi dokument przygotowany przez gen. Wodzickiego - Jak dwoma batalionami i czterema szwadronami miasto Kraków okrywać by można przez kordon posterunkowy przeciwko małym podziałdom [oddziałom] nieprzyjacielskim, aby się nie zaraz w przedmieściu ulokować mogli. Kordon posterunków miał być rozstawiony od Bielan do Dąbia, opierając się oboma skrzydłami o Wisłę. Punkt ciężkości miał się znajdować na lewym skrzydle, gdyż tamtędy wiodły trakty ze Śląska, a prawe miało być jedynie zabezpieczeniem. Pierwsza linia miała być sformowana z jazdy, a druga z piechoty, co było zgodne $\mathrm{z}$ regułami i znajdowało odzwierciedlenie w regulaminach. Na Bielanach oraz Woli Justowskiej stać miała jedna kompania piechoty z komendą strzelców. Przed nimi znajdować się miał szwadron jazdy w Smierdzące (dzisiejszy Kryspinów) i Liszkach, który miał wysyłać patrole w kierunku Alwerni do Poręby (Poręba Żegoty) i Chrzanowa oraz wzdłuż brzegu Wisły. W razie alarmu jazda miała pozostawać na swoich stanowiskach dopóty, dopóki piechota nie zajmie pozycji obronnych, po czym miała się wycofać między Bielanami a Wolą „w miejsce sposobne do oparcia się”, a najlepiej do urządzenia zasadzki. Strzelcy mieli zająć stanowiska w lesie w pobliżu drogi, ubezpieczani przez półkompanię piechoty stojącą za murem bielańskiego klasztoru. Druga półkompania obsadzić miała „Zamek Woli” (Willę Decjusza w Woli Justowskiej) i obserwować drogę biegnącą od Morawicy.

Następna kompania piechoty z komendą strzelców znajdować się miała w Małych i Wielkich Bronowicach. Szwadron jazdy „lokować się” miał w Zabierzowie i patrolować drogi w kierunku Olkusza oraz Krzeszowic. Następne dwie kompanie stacjonować miały w Toniach, przy czym jedna $\mathrm{z}$ nich w razie alarmu zajmować miała Górę Bronowicką, łącząc się tam z kompanią stacjonującą w Bronowicach, a strzelcy obsadzić mieli krzaki. Tym samym kontrolowaliby drogę z Krzeszowic i Olkusza do Krakowa. Pikieta z Bronowic miała obsadzić też ogrody przy Bronowicach Małych, obserwując stamtąd drogę z Morawicy. Druga kompania z Toni miała przejść pomiędzy tę wieś a Zielonki, zabezpieczając tym samym drogi ze Skały i z Olkusza.

93 Jakim sposobem miasto Kraków i Zamek przy teraźniejszej sytuacji postapić sobie mogły podczas alarmu i ataku otoczacego kordon, ANK, Podh. III, VIII 7/9. 
W Zielonkach stacjonować miał półszwadron jazdy, półkompania piechoty i mocna komenda strzelców. Jazda miała patrolować drogę w kierunku Skały, a w razie alarmu wycofać się za wieś. W tym czasie strzelcy powinni obsadzić ogrody i stamtąd ostrzeliwać nadchodzącego drogą nieprzyjaciela. Cug (pluton) piechoty miał w tym czasie obsadzić cmentarz i obserwować drogę biegnącą tamtędy oraz most przy karczmie i młynie.

Kolejny półszwadron jazdy i półkompania piechoty, stacjonujące w Górce i Białym Prądniku, obsadzić powinny w czasie alarmu Witkowice, wystawiając posterunki na Wielkim Pocztowym Trakcie Warszawskim. W czasie alarmu piechota zajmować miała lewe skrzydło w ogrodach wiejskich, obserwując drogę z Zielonek, natomiast jazda stanąć miała przed wsią, obserwując trakt pocztowy.

Dwie kompanie piechoty i cug jazdy miały zajmować Czerwony Prądnik i w razie alarmu stanąć przed wsią. Zadaniem tej grupy miało być wspieranie oddziału stojącego w Witkowicach. Jazda miała patrolować drogę w kierunku Słomnik.

Na koniec na prawym skrzydle wojsk osłaniających Kraków jeden cug kawalerii i półkompania piechoty znajdować się miały w Rakowicach, zasłaniając prawą flankę i obserwując tamtejsze drogi. Do Czyżyn i Mogiły wysunięty miał być półszwadron, a za nim stać miała półkompania w Dąbiu i Piasku. Jazda miała patrolować drogi, a w razie alarmu zająć pozycję za piechotą, która obsadzała wówczas „górę pod kaplicą" (na wschód od Wesołej, przy trakcie na Lublin, ubezpieczone od frontu przez rzeczkę Prądnik) $)^{94}$.

Oba plany sporządzone przez gen. Wodzickiego są niedatowane, ale biorąc pod uwagę następne dokumenty dotyczące problemu obrony Krakowa i Wawelu, musiały zostać przygotowane najpóźniej 3 kwietnia. Co więcej, w obu brakuje informacji, które, ponownie biorąc pod uwagę inne dokumenty, musiały być już sformułowane - dotyczyły one rozmieszczenia artylerii na przedpolu Krakowa oraz kierunku odwrotu zagrożonych posterunków. Otóż z dokumentów z 4 i 6 kwietnia wiadomo, że wobec naporu nieprzyjaciela posterunki z lewego skrzydła (z Bielan i Bronowic) miały wycofywać się razem z artylerią do Krakowa, a następnie na Wawel, zaś z prawego skrzydła, aby uniknąć osaczenia, w kierunku Mogiły ${ }^{95}$. Nie wiadomo jednak, gdzie znajdowały się dwa pozostałe bataliony i były garnizon twierdzy jasnogórskiej (żołnierze z komendy artylerii byli zapewne rozdysponowani do obsługi dział). Tutaj logiczną odpowiedzią jest, że znajdowali się na Wawelu oraz rozdzieleni byli pomiędzy wspomniane w pierwszym dokumencie posterunki na terenie Krakowa.

Rozwinięciem dwóch powyższych planów były Uwagi kpt. Gawłowskiego. Na początek skoncentrował się on na wykorzystaniu posiadanej artylerii - dwóch haubic, dwóch armat 6-funtowych, czterech 3-funtowych i dwóch 1-funtowych. Uznał, że ze względu na niewielką liczbę dział, nie ma możliwości rozmieszczenia ich na fortyfikacjach miejskich. Obronę miasta mogła jednak wspierać artyleria znajdująca się na

${ }^{94}$ Jak dwoma batalionami i czterema szwadronami miasto Kraków okrywać by można przez kordon posterunkowy przeciwko matym podziałdom nieprzyjacielskim, aby się nie zaraz w przedmieściu ulokować mogli, ANK, Podh. III, VIII 7/9.

${ }^{95}$ Rezolucja na uwagi JWP Gawłowskiego [...] względem planty bronienia miasta i zamku krakowskiego przez kordon posterunków, 6 IV 1793 r., ANK, Podh. III, VIII 7/12. 
zamku - dwie armaty 6-funtowe i dwie 3-funtowe oraz jedna haubica (8-funtowa). I na tym stwierdzeniu w zasadzie zakończył problematykę związaną z próbą obrony Krakowa, koncentrując się na możliwości stawienia oporu na Wawelu. Zagrożenie widział przede wszystkim od ulicy Kanoniczej i od klasztoru Bernardynów na Stradomiu. Ponieważ trudno byłoby przetaczać działa pomiędzy zagrożonymi odcinkami, wypadało więc od strony ulicy Kanoniczej w Bramie Zamkowej (Wazów) ustawić dwie armaty, kolejne dwie armaty w Bramie Czerwonej (naprzeciw Furty Pobocznej), a na wale (prawdopodobnie na znajdującej się tam baterii) jedną armatę 6-funtową i jedną haubicę dla ostrzeliwania ulicy Kanoniczej i błonia przed Bramą Wiślaną. Poza tym w nocy z haubicy miały być rzucane karkasy ${ }^{96}$ i fajerbale ${ }^{97}$ dla oświetlenia okolicy i uniemożliwienia nieprzyjacielowi skrytego podejścia pod mury. Natomiast od strony klasztoru Bernardynów na wale należało ustawić trzy działa - jedną armatę koło Baszty Sandomierskiej, drugą koło Baszty Senatorskiej, a haubicę pomiędzy nimi koło Baszty Szlacheckiej ${ }^{98}$. Działa te mogły posłużyć również do wsparcia wycieczki w kierunku klasztoru.

W drugiej części Gawłowski skoncentrował się na możliwościach wykorzystania pozostałych fortyfikacji Wawelu. W najlepszym stanie był odcinek od strony Wisły, ze względu na zakończone prace przy głównym murze, jednakże było tam bardzo mało miejsca do ustawienia i przetaczania armat, ponieważ nie ukończono murów wewnętrznych (a tym samym brakowało tarasów artyleryjskich). Inżynier nie widział też możliwości wspierania artylerią wypadów piechoty z Baszty Złodziejskiej, gdyż nie było tam którędy wyprowadzić armat. Mimo wszystko przygotowując zamek do obrony, należało zdaniem Gawłowskiego ustawić przynajmniej jedną armatę w Baszcie Złodziejskiej lub na dole za „lukarami”.

Tym samym do obrony zamku potrzeba było jego zdaniem przynajmniej ośmiu dział, nad którymi komendę powinno mieć dwóch oficerów. Gawłowski liczył, że pozostałe działa „szczęśliwie” przyprowadzone zostaną na zamek z przedpola przez wycofujące się posterunki. Oczywiście należało też przygotować amunicję artyleryjską - granaty i kartacze oraz karkasy i fajerbale do haubic 8 -funtowych, ładunki z kulami i kartaczami do armat 3-funtowych i ładunki z kartaczami do dwóch armat 1-funtowych. Co ciekawe, kpt. Gawłowski nie wspomina o amunicji do armat 6-funtowych, co może oznaczać, że do tego wagomiaru była odpowiednia liczba gotowych ladunków ${ }^{99}$.

Odnośnie do liczebności garnizonu autor Uwag obliczając długość starych murów zamkowych na 1350 do 1400 łokci, uważał, że potrzeba będzie od 600 do 1000 żołnierzy. Połowa z nich powinna znajdować się na Wawelu już w momencie

96 Pociski oświetlające.

${ }^{97}$ Pociski zapalające.

${ }^{98}$ Gawłowski baszty zamkowe określał mianem wież.

${ }_{99} \mathrm{Na}$ austriackim planie Wawelu z 1796 r. odnotowano, że magazyn z amunicją artyleryjską znajdował się w Baszcie Sandomierskiej. Poza tym amunicję (bez wyszczególnienia rodzaju) przechowywano też w budynku stajni (nieistniejącym obecnie, znajdującym się pomiędzy Kuchniami Królewskimi a kościołem św. Michała), w pomieszczeniach sąsiadujących z murem. Vide: Aufgenommener Plan, das Schloss, 1796. 
podchodzenia wojsk nieprzyjacielskich pod Kraków, a drugą połowę stanowić mieli żołnierze, którzy wycofają się z posterunków znajdujących się przed miastem - wśród nich powinni być wszyscy strzelcy. Na Wawel należało wycofać też „,cokolwiek” kawalerii, wcześniej jednak trzeba było zadbać o zmagazynowanie owsa, siana i słomy.

Na koniec kpt. Gawłowski wskazywał na konieczność przygotowania zapasu żywności oraz węgla, stali, żelaza, drutu, gwoździ, lin, linek i szpagatu. Poza tym potrzebne były kubły, taczki i worki do noszenia ziemi, a także chrust, faszyna i drewno. Sprowadzeni powinni być też cieśle, kowal, birmajster oraz w miarę możliwości ślusarz, stolarz i tokarz z narzędziami ${ }^{100}$.

Odnosząc się do powyższych Uwag, gen. Wodzicki przygotował korektę swojego planu, dzięki której dowiadujemy się, że już wcześniej rozplanował przydział dział i kierunki odwrotów dla posterunków z przedpola. Zamiany podyktowane zostały potrzebą wzmocnienia obrony zamku. Z Witkowic wycofany został oficer $z$ haubicą, gdyż ten posterunek miał być wspierany przez „korpus” z Czerwonego Prądnika, którego zadaniem miał być atak na lewą flankę nieprzyjaciela podchodzącego pod Kraków. Natomiast w razie silnego ataku nieprzyjaciela, oprócz wspomnianych powyżej posterunków z Bielan i Bronowic, na zamek miały się też wycofać oddziały z Toni i Zielonek - piechota i strzelcy razem z artylerią. Odwrót ten miała osłaniać kawaleria powstrzymująca nieprzyjaciela pomiędzy Prądnikiem Białym (Duchownym) a traktem biegnącym do Toni. Dzięki temu obrona Wawelu zostałaby wzmocniona o dwie haubice, dwie armaty 6-funtowe, cztery armaty 3-funtowe, trzy jednorogi 4-funtowe oraz cztery i pół kompanii piechoty z przydzielonymi komendami strzelców.

Co do postulatu Gawłowskiego dotyczącego przygotowania fortyfikacji ziemnych wzmacniających obronę zamku oraz zabezpieczenia wewnętrznych fortyfikacji gen. Wodzicki stwierdził, że potrzebne byłyby na to pieniądze dla najętych robotników, gdyż nie może do tych prac przydzielić żołnierzy - ci mieli obsadzać wyznaczone posterunki. Obiecał przysłać na Wawel kawalerię, po zabezpieczeniu tam dla niej furażu, a cieśli i rusznikarzy mogły dostawić sztaby regimentów. Natomiast co do pozostałych rzemieślników, zaopatrzenia magazynu oraz przygotowania materiałów i „ogniów artylerycznych” należało czekać na zaaprobowanie planu obrony przez „wyższą komendę”, a tym samym wyznaczenie potrzebnych na ten cel funduszy. Miał się tym zająć wyznaczony komendant zamku' ${ }^{101}$.

6 kwietnia gen. Wodzicki odnotował w raporcie dla gen. Ożarowskiego, że wojska pruskie stały w Kromołowie, Siewierzu i Żarkach. Nie miał też pewności, czy będą się dalej posuwać w głąb województwa krakowskiego ${ }^{102}$. Dzień później przygotował nowy podział artylerii wraz z obsługą. Na zamku znajdować się miały dwie haubice 8-funtowe, dwie armaty 6-funtowe i dwie 3-funtowe oraz dwaj oficerowie artylerii: kpt. Antoni Pierściński i por. Jan Sztemberg (ten drugi był oficerem artylerii z twierdzy jasnogórskiej). Na Czerwonym Prądniku dwie armaty 6-funtowe i dwie

${ }^{100}$ ANK, Podh. III, VIII 7/11.

${ }^{101}$ Rezolucja na uwagi JWP Gawłowskiego [...] względem planty bronienia miasta i zamku krakowskiego przez kordon posterunków, 6 IV 1793 r., ANK, Podh. III, VIII 7/12.

102 Wyciag z raportu gen. Wodzickiego, 6 IV 1793 r., ANK, Podh. III, VIII 7/13. 
3-funtowe pod dowództwem por. art. Kazimierza Małachowskiego. W Witkowicach jeden jednoróg 4-funtowy z podoficerem artylerii, a w Toni dwie armaty 3-funtowe, również z podoficerem. $\mathrm{Z}$ kolei na Górze Bronowickiej umieszczona miała być haubica 8 -funtowa i jednoróg 4-funtowy pod komendą por. art. Jana Thielle. Na Woli Justowskiej jeden jednoróg 4-funtowy i w miarę możliwości, a w zasadzie sprawności, jedna lub dwie armatki 1-funtowe z podoficerem artylerii. Natomiast do Bielan przydzielona miała być haubica z jednorogiem pod komendą ppor. art. Antoniego Hoffmana. Łącznie więc na przedpolu znaleźć się miały dwie haubice 8-funtowe, dwie armaty 6-funtowe, cztery armaty 3 -funtowe, cztery jednorogi 4-funtowe i ewentualnie jedna lub dwie armatki 1-funtowe. Do ich obsługi mieli być przydzieleni bombardierzy i kanonierzy oraz ewentualnie żołnierze z regimentów pieszych ${ }^{103}$.

W tym czasie sytuacja w północno-zachodniej części województwa krakowskiego zaczęła się wyjaśniać. Wodzicki w raporcie z 7 kwietnia odnotował, że oddziały pruskie znajdujące się najbliżej Krakowa były w Siewierzu - 150 huzarów, zaś z Kromołowa miały się już cofnąć do Częstochowy. Jednocześnie stwierdził, że poza 9. Regimentem nie miał kontaktu z oddziałami Dywizji Wielkopolskiej, a jedynie wiedział, że najbliżej Krakowa stał 6. Regiment - w Pilicy, Wolbromiu i Szczekocinach. Wątpił też w to, czy w związku z niedostatkiem żywności i furażu możliwa jest koncentracja oddziałów gen. Byszewskiego w województwie krakowskim.

W odpowiedzi gen. Ożarowski stwierdził, że raczej nie podejrzewa, aby Kraków był jeszcze zagrożony atakiem, jednak w ówczesnej sytuacji nie można było odrzucić takiej możliwości. Co do funduszy na umocnienie murów miasta i zamku oraz zaopatrzenie magazynu, to bezskutecznie prosił o nie „Zwierzchność wojskową" i władze konfederackie. W związku z tym w razie marszu Prusaków na Kraków doradzał gen. Wodzickiemu przede wszystkim podjąć próbę zatrzymania ich przed miastem $^{104}$. Zaakceptował tym samym przedstawioną mu koncepcję obrony stolicy województwa.

7 kwietnia Prusy i Rosja ogłosiły manifesty informujące o przeprowadzonej anek$\mathrm{sji}^{105}$. W tym samym czasie oddziały pruskie przestały posuwać się w głąb Małopolski, a nawet cofnęły się w niektórych miejscach (przede wszystkim z Siewierza). Najbliżej Krakowa silne garnizony znajdowały się w Częstochowie - 1500 żołnierzy (dwa bataliony fizylierów oraz pół batalionu dragonów i pół batalionu huzarów), Przyrowie -600 i Koniecpolu - 500 (we wsiach pomiędzy tymi miastami stały posterunki liczące od 20 do 70 żołnierzy ${ }^{106}$. Uspokoiło to sytuację na tyle, aby pod koniec miesiąca dowódcy Dywizji Małopolskiej i Wielkopolskiej udzielili oficerom licznych urlopów. W kolejnych miesiącach głównym problemem stało się zapewnienie oddziałom żywności i furażu oraz utrzymanie żołnierzy w szeregach.

${ }^{103}$ Podzial artylerii na posterunki i do Zamku, gen. J. Wodzicki, Kraków 7 IV 1793 r., ANK, Podh. III, VIII 7/15.

${ }^{104}$ Raport powinny, gen. J. Wodzicki, 7 IV 1793 r., ANK, Podh. III, VIII 7/16.

${ }^{105}$ R.H. Lord, op. cit., s. 228.

106 Raport pptk. J. Grochowskiego z objazdu nowego kordonu polsko-pruskiego, B. Ossol. 11643 Archiwum Wodzickich z Kościelnik. Papiery wojskowe, s. 27. 
Ostatecznie Prusacy podeszli pod Kraków czternaście miesięcy później, w zupełnie innych uwarunkowaniach polityczno-militarnych. Co prawda na przełomie kwietnia i maja 1794 roku miasto zostało zabezpieczone dwuipółkilometrowym wałem o narysie kleszczowym, usypanym na północ od Kleparza ${ }^{107}$, ale ówczesny garnizon (ok. 3500 ludzi) składał się w większości z milicji i kantonistów, a jego komendant miał „słaby charakter i słabszą jeszcze godność obywatelską"108. W związku z tym 15 czerwca Kraków został zajęty niemal bez walki, w wyniku chaosu, jaki zapanował w chwili podejścia żołnierzy pruskich (ok. 2000) na przedpole nowych fortyfikacji. Jedynie 25-osobowy garnizon zamku bronił się do następnego dnia, oddając kilka wystrzałów armatnich ${ }^{109}$.

\section{PODSUMOWANIE}

O tym, że Krakowa najlepiej bronić w polu przed miastem, wiedziano już ponad półtora wieku wcześniej. W 1627 roku kasztelan krakowski Jerzy Zbaraski w liście do króla Zygmunta III stwierdzał: „Nie w murach Kraków, ale przed Krakowem bronić Krakowa potrzeba" ${ }^{110}$. Z tego samego założenia wychodził gen. Wodzicki, zdając sobie sprawę ze słabości fortyfikacji - miejskich, które były przestarzałe i w złym stanie, oraz zamkowych, które były niedokończone i zwrócone w „niewłaściwym” kierunku. Należy jednak podkreślić, że nie planował on uporczywej obrony, a raczej zamierzał przeprowadzić demonstrację i „,pozostawić ślad gwałtu”, jakim były nieuzasadnione i bezprawne działania Prus. Wpływ na to miały ograniczone siły militarne i środki finansowe, jakimi dysponował.

Pruski atak na Kraków wiosną 1793 roku był jednak mało prawdopodobny. Daleko bowiem wykraczał poza styczniowe ustalenia pomiędzy Berlinem a Petersburgiem odnośnie do granicy zaborów i należy wątpić, aby Rosja zgodziła się na zajęcie przez swojego sojusznika tak prestiżowego miasta.

Na koniec należy zauważyć, że wysunięte pozycje obronne, na których gen. Wodzicki zamierzał przyjąć Prusaków, pokrywały się w większości z fortami Twierdzy

107 J. Bogdanowski, Kościuszkowskie fortyfikacje Krakowa [w:] Kraków w powstaniu kościuszkowskim. Materiały sesji naukowej odbytej 28 maja 1994 roku, Kraków 1996, s. 43-47.

${ }_{108}$ Komendantem garnizonu krakowskiego w 1794 r. był gen. mjr Ignacy Wieniawski. Zob. T. Kup czyński, op. cit., s. 206.

109 Ibidem, s. 262-274; B. Szyndler, op. cit., s. 192-196.

110 Należy jednak dodać, że od drugiej połowy XVI w. pojawiały się plany nowoczesnego ufortyfikowania Krakowa (najbardziej ambitny autorstwa francuskiego inżyniera z czasów konfederacji barskiej). Dwukrotnie też doszło do ich realizacji - w 1587 r. Jan Zamoyski otoczył miasto szańcami ziemnymi, aby powstrzymać atak arcyks. Maksymiliana, a w latach 1655-1657 podobnie postąpili Szwedzi przeciw Polakom i Austriakom. Jednakże ze względów finansowych fortyfikacje te nie zostały utrzymane. Zob. J. Bogdanowski, Warownie i zieleń Twierdzy Kraków, Kraków 1979, s. 54-62. 
Kraków wybudowanymi przez Austriaków w drugiej połowie XIX wieku ${ }^{111}$. Tym samym można uznać, iż dokonał trafnego wyboru stanowisk, jakkolwiek wówczas miały one być tylko pozycjami opóźniającymi marsz nieprzyjaciela na miasto.

\section{BIBLIOGRAFIA}

\section{Źródła archiwalne}

Archiwum Jasnogórskie

Actorum Provinciae Polonae, t. XIII, sygn. 543

Archiwum Narodowe w Krakowie

Akta Konfederacji Targowickiej Województwa Krakowskiego, sygn. 4, 5, 7

Archiwum Sanguszków. Podhorce III

Podh. II, 365

Podh. III, V 2/26-27

Podh. III, VIII $4 / 30$

Podh. III, VIII 5/ 31, 33, 37, 40

Podh. III, VIII 6/5, 7-11, 14-15

Podh. III, VIII 7/1-9, 11-13, 15-16, 19

Archiwum Młynowskie Chodkiewiczów, 1160

Zbiór Ambrożego Grabowskiego, sygn. 32

Biblioteka Kórnicka Polskiej Akademii Nauk

BK 0920

Biblioteka Książąt Czartoryskich w Krakowie, 11617

Biblioteka Zakładu Narodowego im. Ossolińskich we Wrocławiu

Archiwum Wodzickich z Kościelnik, 11639, 11641, 11643

\section{Plany}

Aufgenommener Plan, das Schloss und die nächst angrenzenden Gegenden von Krakau, 1796, AT-OeStA KA KPS KS G I h, 330.

Plan der Stadt Krakau, Handzeichnung, ca. 1780 [ok. 1770?], http://www.deutschefotothek. de/documents/obj/70400121.

Plan der Stadt und Schloss Cracau und Casimir Stadt, 1794, Staatsbibliothek zu Berlin, Kartenabteilung, sygn. SBB III C, Kart X, 38027.

Plan von Crakau, Staatsbibliothek zu Berlin, Kartenabteilung, sygn. SBB III C, Kart X, 38026.

Planta miasta Krakowa z przedmieściami roku MDCCLXXXV zrobiona, tzw. kołłątajowski z 1785, Muzeum Krakowa, sygn. 31.

111 W latach 1796-1809 Austriacy nie podjęli realnych działań w celu ufortyfikowania Krakowa, co zaowocowało jego łatwym przejęciem przez wojska Księstwa Warszawskiego. Należy jednak odnotować, że w 1797 r. wyznaczyli komendę placu Twierdzy Kraków (która funkcjonowała do 1805 r.), ale projekty jej wzniesienia pozostały wyłącznie na papierze. Zob. M. Baczkowski, Fortyfikacje w Galicji w latach 1772-1815 [w:] Twierdze osiemnastowiecznej Europy ..., s. 300. 


\section{Źródła drukowane}

Instrukcje i raporty Karola Sierakowskiego dotyczace wywiadu terenowego w przygotowaniach do wojny z Austria w 1790 r., oprac. J. Giergielewicz, „Przegląd Historyczno-Wojskowy” 1929, z. 1.

Jenerała Henryka Dąbrowskiego pamiętnik wojskowy Legionów Polskich we Włoszech poparty notami wyjaśniającymi, Poznań 1864.

[Kratzer Franciszek], Pamiętnik kantora katedry krakowskiej, „Biblioteka Warszawska” 1879 , t. 2.

[Lichocki Filip], Dyaryusz przyjazdu Nayjaśnieyszego Stanisława Augusts [...] do stołecznego miasta Krakowa, Kraków 1787.

Rękopiśmienne plany Wawelu z końca XVIII wieku w Bibliotece Uniwersyteckiej $w$ Wilnie, oprac. K. Dzikowski, „Przegląd Historyczno-Wojskowy” 1936, z. 1.

\section{Opracowania}

Baczkowski M., Fortyfikacje w Galicji w latach 1772-1815 [w:] Twierdze osiemnastowiecznej Europy. Studia z dziejów osiemnastowiecznej sztuki wojskowej, red. M. Trąbski, t. II, Częstochowa 2018.

Bogdanowski J., Kościuszkowskie fortyfikacje Krakowa [w:] Kraków w powstaniu kościuszkowskim. Materiały sesji naukowej odbytej 28 maja 1994 roku, Kraków 1996.

Bogdanowski J., Warownie i zieleń Twierdzy Kraków, Kraków 1979.

Firlet J., Pianowski Z., Fortyfikacje kleszczowe zachodniej części wzgórza wawelskiego, „Teka Komisji Urbanistyki i Architektury” 1979, t. 13.

Giergielewicz J., Zarys historii korpusu inżynierów w epoce Stanisława Augusta, Warszawa 1933.

Grabowski A., Dawne zabytki miasta Krakowa. Przypomnienia przeszłości o niektórych starożytnych zwyczajach mieszczan krakowskich, o bramach, basztach $i$ wszelakich tej niegdyś stolicy kraju obronach, z dodatkiem różnych do dziedziny pamiątek należacych wiadomości, Kraków 1850.

Grabowski A., Historyczny opis miasta Krakowa i jego okolic [...] (Z rycinami), Kraków 1822.

Jędrzejewski P., Krakowski zespół miejski-zróżnicowanie społeczne i zmiany administracyjne $w$ dobie Sejmu Wielkiego, „Małopolska - regiony, regionalizmy, małe ojczyzny” 2014 , t. XVI.

Korzon T., Wewnętrzne dzieje Polski za Stanisława Augusta (1764-1794): badania historyczne ze stanowiska ekonomicznego i administracyjnego, t. 5-6, Kraków 1897.

Kupczyński T., Kraków w powstaniu kościuszkowskim, Kraków 1912.

Lord R.H., Drugi rozbiór Polski, Warszawa 1984.

Małecki J.M., Kraków w dobie oświecenia [w:] Dzieje Krakowa, t. 2: Kraków w wiekach XVI-XVIII, red. J. Bieniarzówna, J.M. Małecki, Kraków 1994.

Muczkowski J., Dawne warownie krakowskie, „Rocznik Krakowski” 1991, t. XIII.

Müller M.G., Rozbiory Polski. Historia Polski i Europy XVIII wieku, thum. M. Wrzosek-Müller, Poznań 2005.

Niewalda W., Rojkowska H., Fortyfikacje kleszczowe Wawelu. Badania architektoniczne elewacji zewnętrznych, „Studia Waweliana” 1996, t. V. 
Pachoński J., Dawne mury floriańskie, Kraków 1956.

Pianowski Z., Wawel obronny. Zarys przemian fortyfikacji grodu i zamku krakowskiego w. IX-XIX, Kraków 1991.

Rawski T., Najście pruskie [w:] Powstanie kościuszkowskie 1794. Dzieje militarne, Warszawa 1994.

Rederowa D., Studia nad wewnętrznymi dziejami Krakowa porozbiorowego (1796-1809), cz. II: Zagadnienia ustrojowe i ekonomiczno-społeczne, „Rocznik Krakowski” 1962, t. XXXVI.

Smoleński W., Konfederacja Targowicka, Kraków 1903.

Szyndler B., Powstanie kościuszkowskie 1794, Warszawa 2001.

Tobiasz M., Fortyfikacje dawnego Krakowa, Kraków 1973.

Trąbski M., Artyleria wojska koronnego w pierwszym etapie powstania kościuszkowskiego (bitwy pod Racławicami i Szczekocinami) [w:] Wśród dymu i ognia. Studia i materiaty do dziejów artylerii polskiej i obcej, t. II, red. A. Smoliński, Oświęcim 2016.

Trąbski M., Twierdza częstochowska w latach Sejmu Czteroletniego i rządów targowiczan (1788-1793) [w:] Twierdze osiemnastowiecznej Europy. Studia z dziejów osiemnastowiecznej sztuki wojskowej, red. M. Trąbski, t. II, Częstochowa 2018. 